\title{
HAI, a new airborne, absolute, twin dual-channel, multi-phase TDLAS-hygrometer: background, design, setup, and first flight data
}

\author{
Bernhard Buchholz $^{1,2, a}$, Armin Afchine ${ }^{4}$, Alexander Klein ${ }^{1}$, Cornelius Schiller ${ }^{4, \dagger}$, Martina Krämer ${ }^{4}$, and \\ Volker Ebert ${ }^{1,2,3}$ \\ ${ }^{1}$ Physikalisch-Technische Bundesanstalt Braunschweig, Braunschweig, Germany \\ ${ }^{2}$ Physikalisch Chemisches Institut, Universität Heidelberg, Heidelberg, Germany \\ ${ }^{3}$ Center of Smart Interfaces, Technische Universität Darmstadt, Darmstadt, Germany \\ ${ }^{4}$ Forschungszentrum Jülich, IEK-7, Jülich, Germany \\ ${ }^{a}$ currently at: Department of Civil and Environmental Engineering, Princeton University, Princeton, USA \\ $\dagger$ deceased
}

Correspondence to: Volker Ebert (volker.ebert@ptb.de)

Received: 16 May 2016 - Published in Atmos. Meas. Tech. Discuss.: 20 May 2016

Revised: 11 October 2016 - Accepted: 17 November 2016 - Published: 3 January 2017

\begin{abstract}
The novel Hygrometer for Atmospheric Investigation (HAI) realizes a unique concept for simultaneous gas-phase and total (gas-phase + evaporated cloud particles) water measurements. It has been developed and successfully deployed for the first time on the German HALO research aircraft. This new instrument combines direct tunable diode laser absorption spectroscopy (dTDLAS) with a firstprinciple evaluation method to allow absolute water vapor measurements without any initial or repetitive sensor calibration using a reference gas or a reference humidity generator. HAI contains two completely independent dual-channel (closed-path, open-path) spectrometers, one at 1.4 and one at $2.6 \mu \mathrm{m}$, which together allow us to cover the entire atmospheric $\mathrm{H}_{2} \mathrm{O}$ range from 1 to 40000 ppmv with a single instrument. Both spectrometers each comprise a separate, wavelength-individual extractive, closed-path cell for total water (ice and gas-phase) measurements. Additionally, both spectrometers couple light into a common open-path cell outside of the aircraft fuselage for a direct, sampling-free, and contactless determination of the gas-phase water content. This novel twin dual-channel setup allows for the first time multiple self-validation functions, in particular a reliable, direct, in-flight validation of the open-path channels. During the first field campaigns, the in-flight deviations between the independent and calibration-free channels (i.e., closed-path to closed-path and open-path to closed-path) were on average in the $2 \%$ range. Further, the fully autonomous HAI hy-
\end{abstract}

grometer allows measurements up to $240 \mathrm{~Hz}$ with a minimal integration time of $1.4 \mathrm{~ms}$. The best precision is achieved by the $1.4 \mu \mathrm{m}$ closed-path cell at $3.8 \mathrm{~Hz}(0.18 \mathrm{ppmv})$ and by the $2.6 \mu \mathrm{m}$ closed-path cell at $13 \mathrm{~Hz}(0.055 \mathrm{ppmv})$. The requirements, design, operation principle, and first in-flight performance of the hygrometer are described and discussed in this work.

\section{Introduction}

\subsection{Atmospheric water vapor}

Water vapor is in many ways one of the most important measurand for atmospheric investigations (Ludlam, 1980; Möller et al., 2011; Ravishankara, 2012). Water vapor is the most important greenhouse gas (Kiehl and Trenberth, 1997) and is known as a key atmospheric coupling element of almost all microscopic (e.g., droplets and ice crystals formation), macroscopic (e.g., clouds and precipitation), and global processes (e.g., hydrological cycle). It is strongly related to numerous highly relevant topics of atmospheric science and closely related to climate change (Held and Soden, 2000; Houghton, 2009; Kiehl and Trenberth, 1997; Maycock et al., 2011). Unsurprisingly, numerous water vapor studies have been carried out targeting its atmospheric trends and variability (Lu and Takle, 2010; McCarthy et al., 2009; Ross and 
Elliott, 1996; Scherer et al., 2008; Trenberth et al., 2005; Xie et al., 2011), its influence on transport models (Kiemle et al., 2012; Schäfler et al., 2010), or its impact on radiation balance models (Lockwood, 1990; Ramanathan et al., 1989; Schneider, 1972). The high complexity of atmospheric water vapor is linked to its occurrence in all three phases, which is unique among most atmospheric molecules. Water in the gas phase is a very strong infrared absorber and significantly impacts atmospheric energy fluxes through latent heat transfers by the different phase transitions. Condensation to the liquid phase or freezing to solid particles leads to effective scattering of solar radiation, which directly raises links to the formation process of cirrus clouds (Krämer et al., 2009; Spichtinger et al., 2004). These few relationships show the complexity from a theoretical as well as a modeling point of view. Today, however, the quality (particularly accuracy and comparability) of atmospheric water measurements frequently limits a better understanding of key atmospheric processes (Krämer et al., 2009; Peter et al., 2006; Scherer et al., 2008; Sherwood et al., 2014). Despite the outlined importance and the large effort invested in the developments of hygrometers in recent years, water vapor remains a target molecule that is very difficult to measure accurately.

Several major issues exacerbate airborne water vapor measurements. Atmospheric water vapor encompasses a very large concentration range (3-40 $000 \mathrm{ppmv})$. The high spatial variability of $\mathrm{H}_{2} \mathrm{O}$ leads, on fast aircraft (typically around $800 \mathrm{~km} \mathrm{~h}^{-1}$ cruising speed), to highly dynamic $\mathrm{H}_{2} \mathrm{O}$ variations in airborne measurements of up to several $1000 \mathrm{ppmv} \mathrm{s}^{-1}$ in the gas phase and several $10000 \mathrm{ppmv} \mathrm{s}^{-1}$ for total water (gas phase + evaporated ice or liquid phase). Airborne hygrometers thus require high time resolution, precision, and accuracy at the same time. Additionally, water vapor is very effectively absorbed from nearly any surface. This challenges in a highly complex manner not only the entire gas sampling system but also the calibration infrastructure which is typically required for most hygrometers. By waiving the entire calibration process, special laser-based hygrometers (Wolfrum et al., 2011) circumvent all calibration-related issues efficiently which will be explained later in Sect. 3.2. Last but not least, the measurement boundary condition, such as gas pressure, gas temperature, gas velocity, instrument operation temperature changes, or vibrations during airborne measurement, is defined by the environment inside and outside of the aircraft itself causing a variety of complications.

\subsection{Airborne hygrometry}

This brief compilation illustrates the complex challenges associated with developing airborne water vapor instruments, especially to measure at tropospheric and stratospheric atmospheric conditions. A high number of (mostly single channel and single $\mathrm{H}_{2} \mathrm{O}$ phase) hygrometers have been developed in the last decades with various advantages and drawbacks (Wiederhold, 1997). A non-exhaustive selection of instru- ments has been described (Buck, 1985; Busen and Buck, 1995; Cerni, 1994; Desjardins et al., 1989; Diskin et al., 2002; Durry et al., 2008; Ebert et al., 2000b; Gurlit et al., 2005; Hansford et al., 2006; Helten et al., 1998; Hunsmann et al., 2008; Karpechko et al., 2014; Kley and Stone, 1978; May, 1998; Meyer et al., 2015; Ohtaki and Matsui, 1982; Roths and Busen, 1996; Salasmaa and Kostamo, 1986; Sargent et al., 2013; Schiff et al., 1994; Silver and Hovde, 1994b, a; Thornberry et al., 2015; Webster et al., 2004; Zöger et al., 1999a, b; Zondlo et al., 2010). Consequently, the question should be raised from the opposite point of view: What are the important and required properties to be covered and combined for the near-universal Hygrometer for Atmospheric Investigation (HAI) to serve as an innovative and cutting-edge tool to explore open and new scientific questions related to atmospheric water vapor?

\section{General design targets for HAI}

\subsection{Open-path, closed-path, or both?}

It is highly desirable for an airborne system to be constructed so that it operates on the ground in the same manner as in flight and that every change of environment and "boundary conditions" of the instrument is logged and supervised and impacts are minimized or even prevented by design. This allows extensive validation as well as laboratory comparisons with other instruments and avoids systematic, barely detectable deviations only occurring in flight. Instruments that are calibrated/validated on the ground in different configurations (such as in Diskin et al., 2002) or under different working conditions (such as in Sargent et al., 2013) often fail to provide a clear, reliable, unbroken chain of calibrations from the in-flight measurement to a (metrological) laboratory standard, which is necessary to guarantee accuracy.

This notion related to water vapor leads directly into the everlasting discussion about sampling via open-path systems operation in the free flow versus closed-path systems extracting the air to be analyzed into the instrument. Open-path hygrometers offer numerous great benefits such as the prevention of any sampling errors or uncertainties (caused by surface absorbing effects) as well as the high response time that is limited by the transfer functions of optical or electrical components but not by the gas exchange rate. The latter circumvents the complicated and adulterant deconvolution of smoothing effects with time-response functions caused by a sampling system. However, the boundary conditions such as gas pressure and gas temperature as well as possible spatial inhomogeneity of both parameters are difficult to take accurately into account for an open-path system. Additionally, an airborne open-path sensor has to operate in harsh boundary conditions, i.e., over a large range of temperatures $\left(-80\right.$ to $\left.50^{\circ} \mathrm{C}\right)$ and pressures $(70$ to $1000 \mathrm{hPa}$ ), for large ram 
pressures (900 $\mathrm{km} \mathrm{h}^{-1}$ gas velocity) and mechanical stress through accretion of ice or liquid water.

The major problem of all present open-path systems is their highly complex calibration, or even just validation, since realistic flight conditions, in particular the dynamics, are extremely difficult to realize in a lab with sufficient accuracy. A direct metrological link to test the in-flight performance, e.g., a dynamic calibration facility for open-path hygrometers, is therefore missing.

Closed-path systems, in contrast, are simply installed inside an air-conditioned cabin in a much more protected environment. Gas is sampled with a suitable inlet and led via a tubing system to an "internal" measurement chamber, such as an optical absorption cell or a "cavity", e.g., for a dewpoint mirror hygrometer (DPH). On one hand, it is much easier to accurately control and maintain the physical boundary conditions of the sample gas, e.g., temperature, pressure, and flow, in the measurement volume. On the other hand, it is difficult to ensure and maintain a representative sampling process and to quantify and correct sampling related deviations. These may be caused by adsorption and desorption effects, which occur on all surfaces of the sampling system and have to be carefully minimized, for example by heated (HAI $\approx 80^{\circ} \mathrm{C}$ ), electro-polished stainless steel sampling pipes, along with an instrument design ensuring high gas flows $\left(\mathrm{HAI} \approx 100 \mathrm{~L} \mathrm{~min}^{-1}\right.$ ) under all flight conditions.

Gas-phase $\mathrm{H}_{2} \mathrm{O}$ measurements in clouds are often carried out via backward-facing sampling inlets. However, such inlets readily sample small liquid or solid water particles, possibly causing systematically positive offsets. The measurement of total water, i.e., the sum of water in the gas phase as well as in the condensed phase (ice and droplets), relies additionally on an accurate distribution model of the particles entering the inlet system. Usually, the particle sampling characteristics are considered individually (Krämer and Afchine, 2004), and sampling corrections are done during further metrological analysis and therefore not part of an instrument description. For every $\mathrm{H}_{2} \mathrm{O}$ measurement using airborne extractive (closed-path) instruments on aircraft, it needs to be taken into account that the instruments response reflects contributions from the sensor element itself as well as the sampling system and its dynamic properties.

One major indisputable advantage of typical extractive (closed-path) instruments is the possibility for careful tests outside of the aircraft, i.e., in a hangar or laboratory. However, to take full advantage of this, it is desirable for a sophisticated instrument to integrate supervising and monitoring functions in a way that a performance comparable to the laboratory can be ensured during any in-flight situation. This generates the great benefit of transferring the performance from laboratory to field, quite similar to how a metrological transfer standard is typically used. This directly reinforces the question of how to assess the accuracy of airborne hygrometers on ground and in particular during flight operation.

\subsection{State-of-the-art instrument accuracy}

In general, the highest measurement and preparation accuracy is realized by the validated primary standards of national metrology institutes such as PTB (Germany) or NIST (USA). The international metrological water vapor scale is defined by traceable primary water vapor generators (Brewer et al., 2011). The mixing ratio range, required to cover the entire tropospheric and stratospheric range (3-40 000 ppmv), is realized by a combination of generators based on different physical principles. Their uncertainty is on the order of $0.5 \%$ relative (Brewer et al., 2011; Buchholz et al., 2014a; Mackrodt, 2012). In other words, it is not possible to validate any hygrometer with a better accuracy due to the lack of a suitable accurate reference.

Comparing the available metrological accuracy to some results from field comparisons of airborne hygrometers demonstrates the large potential for improvement. For example, long-term ( $>10$ years) change studies of stratospheric $\mathrm{H}_{2} \mathrm{O}$ (Oltmans and Hofmann, 1995; Rosenlof et al., 2001; Solomon et al., 2010) suffer from significant, difficult to quantify relative deviations between different instruments in the range of 50-100\% (Fahey et al., 2014; Peter et al., 2006; Vömel et al., 2007), which recent studies (such as Rollins et al., 2014) confirm ( $\pm 40-50 \%$ for $<3$ ppmv and $\pm 20 \%$ for $>3$ ppmv). Radiosonde comparisons with polymer sensors and chilled DPH, covering the entire troposphere and lowerstratospheric region (such as Miloshevich et al., 2006), show averaged overall agreements in the $10 \%$ range (as well as local deviations in the $30 \%$ range). These deviations are quite common for many airborne campaign results (e.g., Smit et al., 2014) and become even worse when focusing on the relative deviations in regions containing highly variable $\mathrm{H}_{2} \mathrm{O}$ structures. Hence in 2007, an international comparison exercise, "AquaVIT" (Fahey and Gao, 2009), was organized to compare the world's best airborne hygrometers under wellcontrolled, quasi-static, equivalent conditions to evaluate the accuracy under well-controlled laboratory conditions, without the influence of any typical dynamic sampling effects. AquaVIT comprised 22 hygrometers (tunable diode laser spectrometers (TDL), dew- or frost-point mirror hygrometers (D/FPH), Lyman alpha fluorescence and absorption hygrometers (LAFH), and other principles) from 17 international research groups. The instruments were categorized in well-validated "core" instruments (APicT, FISH, FLASH, HWV, JLH, CFH; see Fahey and Gao, 2009, for details) and "younger, less mature" non-core instruments. Even the core hygrometers deviated in the important 1 to $150 \mathrm{ppmv}$ $\mathrm{H}_{2} \mathrm{O}$ concentration range by up to $\pm 10 \%$ from their common mean value. In other words, core instruments differed by up to $20 \%$ from each other, even under quasi-static conditions. Other, less representative and extensive, comparisons (such as Hoff, 2009; Mangold and Wodca Team, 2003) yielded similar results. 


\subsection{Educated guess for accuracy deviations between state-of-the-art hygrometers}

The assessment of the required accuracy depends strongly on the purpose of the instrument and its data. For commonly used climatologies or strongly averaged coarse validation studies, larger deviations can be acceptable. In many other cases such as the currently often discussed atmospheric supersaturations (Peter et al., 2006), the instrument uncertainties prevent deeper investigations and therefore a better understanding. Reconsidering the entire situation and seeing that after so many development efforts over the past decades these deviations remain quite high leads to the inevitable question of concealed, common impact factors. Contemplating the typical metrological efforts needed at national metrology institutes (NMIs) to generate an accurately humidified gas stream (with a sub-percent uncertainty) suggests that the uncertainties generated by typical calibration processes under field conditions could be a major contribution to these hygrometers deviations found in AquaVIT and other studies. In particular, comparing the performance and strategies of lab-based, metrological, and portable field calibration facilities (Friehe et al., 1986; Helten et al., 1998; Podolske et al., 2003; Smit et al., 2000; Smorgon et al., 2014; Zöger et al., 1999b) indicates three significant discrepancies: required time for calibration, frequency of calibration, and traceability of the humidity reference itself. Calibrations in low concentration ranges at NMIs take several hours up to days per individual humidity value. During airborne campaigns, however, calibrations often have to be realized (for practical reasons) in a short time, certainly less than a few hours for a large number of concentration steps often including several pressure levels, thereby taking the obvious risk that the instrument/reference is not fully stabilized or equilibrated. Ideally, the time between two calibrations should be shorter than the expected time required for a drift/change exceeding the boundaries of the instrument uncertainties. Some airborne instruments require for the same reason calibrations before and after each flight in order to interpolate between both calibrations (Zöger et al., 1999b). Some even work with in-flight calibrations (Kaufmann et al., 2016; Thornberry et al., 2013), sacrificing measurement time and shifting the accuracy issue to the necessary airborne $\mathrm{H}_{2} \mathrm{O}$ source. Undoubtedly, many of these instruments have benefits, for example in terms of precision, space, weight, and prime cost, which justify the calibration effort. In contrast, it is often condoned that the calibration process is hampered and turns out to be the major influence on the accuracy of such a sensor.

Lastly, it seems necessary to implement a traceable link to the metrological humidity scales to improve the overall accuracy of airborne hygrometry (Joint Committee for Guides in Metrology (JCGM), 2009). By realizing an unbroken chain of calibrations, it is possible to link the instrument performance and the metrological water scale to the SI system of units. This guarantees an accurate measurement/generation value with defined uncertainties.

To summarize, fulfilling all these demands in the field similar to an NMI laboratory is a tough task. However, as discussed later, many of the covered issues can be circumvented using first-principle techniques like direct tunable diode laser absorption spectroscopy (dTDLAS; Ebert and Wolfrum, 1994; Schulz et al., 2007) to realize optical, absolute hygrometers which avoid over-defined operating ranges and water vapor sensor calibration.

\subsection{Precision and time response of state-of-the-art instrumentation}

From a user's point of view, precision and response time of an airborne hygrometer appear equivalent to accuracy if one is interested in fine structure resolving data. Precision and response time are, under certain circumstances, reciprocally correlated to each other (Allan, 1966). Typical figures for response time of airborne hygrometers in the literature are 0.5$1 \mathrm{~Hz}$ (Petersen et al., 2010; Szakáll et al., 2004; Zöger et al., $1999 \mathrm{~b}$ ); some instruments deliver faster data of $4 \mathrm{~Hz}$ (Weinstock et al., 1994) and up to $25 \mathrm{~Hz}$ (Zondlo et al., 2010). Typical precisions at $1 \mathrm{~Hz}$ are in the range of $0.1-0.2 \mathrm{ppmv}$ (Sargent et al., 2013; Zöger et al., 1999b; Zondlo et al., 2010). While in the stratosphere $(<10 \mathrm{ppm})$, the precision certainly can become a limiting factor; this is much less the case inside clouds or within the troposphere, where frequent, very strong, spatial variations (up to $1000 \mathrm{ppmv}$ per $100 \mathrm{~m}$ flight path in the gas phase or up to 20000 ppmv per $100 \mathrm{~m}$ during total water phase) pose a larger problem. An instrument with a time response of just a few hertz causes significant undersampling, which can lead to strong aliasing effects at standard cruising speed of research aircraft (approximately $700-900 \mathrm{~km} \mathrm{~h}^{-1}$ ). Important under such conditions is the instrument's linearity and range to accurately cover the entire $\mathrm{H}_{2} \mathrm{O}$ concentration range up to 5 magnitudes for total water vapor measurements without cutoffs or complex deconvolution functions.

\subsection{Other requirements guiding the design}

HAI was designed for the German HALO aircraft (HALO, 2016; Krautstrunk and Giez, 2012), a Gulfstream G500, similar to the American HIAPER (UCAR/NCAR, 2016), which is a Gulfstream G500. HALO offers broad spatial coverage $(>10000 \mathrm{~km})$, high altitudes (up to $15 \mathrm{~km})$, large payloads of up to $3000 \mathrm{~kg}$, and a pressurized and air-conditioned cabin. Due to the high operation costs for aircraft and the high scientific demand, $\mathrm{H}_{2} \mathrm{O}$ data have to be measured continuously without any interruptions. The instrument thus has to be highly reliable, robust, require low maintenance, and conduct an entirely automatic and autonomous startup procedure. The restrictions in weight and space as associated with operation on aircraft result in the necessity for a compact and 
lightweight construction. The utterly complex and mandatory certification process (at least in Germany) enforces an instrument design freeze before a campaign; this results in very stiff constraints for improvements and repairs during a campaign.

\section{$3 \quad \mathrm{H}_{2} \mathrm{O}$ spectroscopy related to the $\mathrm{HAI}$ instrument}

HAI consists of four independent but interconnected spectrometers. For each individual channel an individual evaluation procedure is done following an identical, common spectroscopic method: calibration-free dTDLAS.

\subsection{Direct tunable diode laser absorption spectroscopy}

The requirements for fast measurements and high chemical selectivity in combination with a robust and small system calls for a contactless spectroscopic (hence optical) measurement technique rather than contact sensing methods such as DPH or capacitive polymer sensors. The latter (e.g., HUMICAP, Vaisala, used in Salasmaa and Kostamo, 1986, and Smit et al., 2000) is quite frequently used in meteorological environments for weight, size, and cost reasons (Busen and Buck, 1995; Hansford et al., 2006; Wiederhold, 1997). By choice of the spectroscopic method, optical hygrometers can be set up to become quite immune to hydrophobic substances (unavoidable in the vicinity of aircraft) as well as particles (dust, soot, ice, etc.) carried by the gas to be analyzed. These capabilities were, for example, extensively demonstrated via measurements inside of combustion processes in industrial power plants (Ebert et al., 2000a; Schlosser et al., 2002; Sun et al., 2013; Teichert et al., 2003).

TDLAS, especially in the near infrared spectral range, is a powerful as well as versatile diagnostic technique and has led to numerous applications in atmospheric hygrometry (Diskin et al., 2002; Fahey and Gao, 2009; Gurlit et al., 2005; May, 1998; Schiff et al., 1994; Thornberry et al., 2015). Advantageous properties of diode lasers are very high spectral resolution (providing excellent chemical selectivity), high power density, and continuous wavelength tunability in combination with interesting technical features such as low cost, very low size/weight/power consumption, long lifetime, excellent beam quality, and optical fiber coupling to name just a few.

The typical setup and working principle of a TDLAS instrument has been frequently described in detail (Lackner, 2011; Schiff et al., 1994; Schulz et al., 2007; Werle, 1998). Therefore, only HAI's design relevant topics are discussed. Important for an understanding of the novel HAI instrument is the classification of TDLAS instruments by their optical detection schemes in classical single- (Ebert et al., 2000b) or multi-path (Gurlit et al., 2005; Hunsmann et al., 2008; Lübken et al., 1999; May, 1998; McManus et al., 1995) beam setups. In general, longer path lengths - achieved by multipath optics with a high number of reflections - provide better sensitivity. However, higher reflection numbers are also more critical to align. Compared to most airborne TDLAS instruments, HAI has a relatively low number of reflections and thus relatively short path lengths. Further categorizing distinguishes between wavelength-modulation schemes like single modulation frequency, called direct TDLAS or dTDLAS (Ebert and Wolfrum, 1994), or double modulation schemes like wavelength modulation spectroscopy (WMS) (Podolske and Loewenstein, 1993; Silver, 1992; Silver and Hovde, 1994a; Silver and Zondlo, 2006; Vance et al., 2011; Webster et al., 2004). WMS, often used for very compact sensors, provides on the first glance higher sensitivities by using lock-in technologies to efficiently filter noise. This, however, sacrifices the possibility of direct physics-based quality and reliability checks, since the actual measured WMS raw signal contains less spectral information than a dTDLAS raw signal. This aggravates or sometimes even prevents detailed signal analysis based on fundamental physical explanations. Using dTDLAS instead with a special, but less common, firstprinciple evaluation procedure (Ebert and Wolfrum, 2000; Farooq et al., 2008; Mihalcea et al., 1997; Schulz et al., 2007) allows sophisticated evaluation, characterization, quality management and a holistic view on the physical principles behind the data. This circumstance can even be used to avoid typical calibration procedures with reference gas standards as demonstrated in Buchholz et al. (2013b).

\subsection{1 "Calibration-free" TDLAS: an explanation of the term}

The term "calibration-free" is often used in different communities with dissimilar meanings. To distinguish, one should consider how calibration is defined by metrology (JCGM 2008, 2008): "calibration (...) in a first step, establishes a relation between the measured values of a quantity with measurement uncertainties provided by a measurement standard (...) [I]n a second step, this information is used to establish a relation for obtaining a measurement result from an indication (of the device to be calibrated)". In other words, an instrument with a deterministic relation between indication and measured quantity can be kind of "brute-force" calibrated, without knowing the physical details behind the measurement process. This is often used to compensate nonlinearities, offsets, drifts or response changes over time as long as they are stable, predictable, or can be extrapolated. Again, the causes and physical explanation of this disadvantageous behavior are then neither known nor understood - it is only corrected for.

For HAI we use the term "calibration-free" to emphasize that HAI does not rely on such a correction process. This means that the hygrometer described in this paper is neither initially calibrated (i.e., like the factory calibration of a commercial instrument) nor is it regularly calibrated or adjusted by a repetitive comparison to a water vapor primary standard. Parameters like gas pressure and temperature that are 


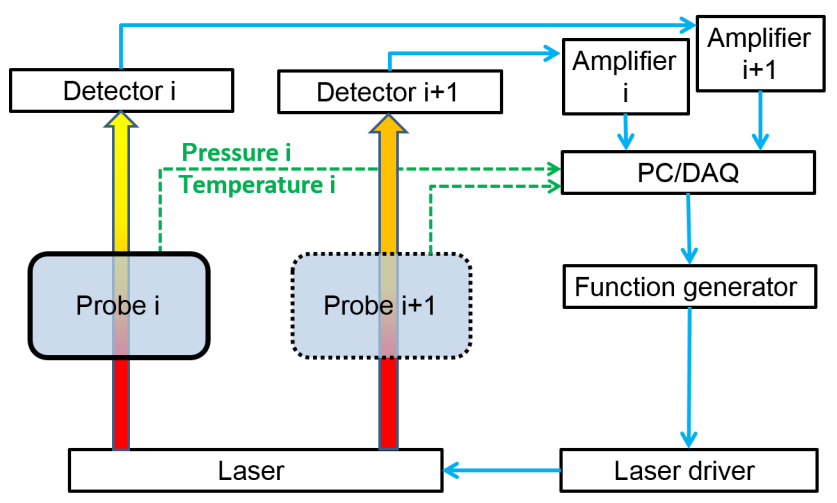

Figure 1. Simplified schematic of a standard dTDLAS setup with several spectroscopic channels: HAI combines two lasers (one at $1.4 \mu \mathrm{m}$ for high, one at $2.6 \mu \mathrm{m}$ for low water vapor concentrations), with two locations cells $(1 \times$ open-path and $2 \times$ closed-path), and supplementary spectroscopic channels (parasitic water detector (Buchholz and Ebert, 2014b) and reference cell for spectral stabilization). HAI has in total seven spectroscopic channels.

used for the calculation of the water vapor content via our first-principle spectrophysics model are of course measured with classically calibrated sensors. This is done from a practical point because (a) primary standards for temperature and pressure are by themselves large facilities and (b) the influence in the final uncertainty budget does not justify a firstprinciple approach for pressure and temperature too. Thus, calibration-free does not mean that all measurement parameters in the entire setup are based on principles. The whole idea behind traceability (JCGM 2008, 2008) is to use other units, higher in the hierarchy of the SI units to generate and analyze the target value. In metrology, this is named "an unbroken chain of measurements". To visualize, this means that the first and initial measurement result of the HAI instrument delivers the final concentration value. There is no subsequent "adjustment process" to "tune" an intermediate result towards a target value defined by a higher reference standard. The HAI evaluation directly delivers final values. This requires that the entire measurement system be characterized in advance on such a level that, for example, all influences of the instrument temperature on the end value are characterized and the very first measurement value is already determined within its uncertainty limits. Therefore, since there was no calibration, it is termed calibration free.

The uncertainty budget of HAI's calibrated sub-sensors, e.g., pressure and temperature, also has to contain a p-T sensor drift consideration between two calibration cycles of these p-T sensors. Sufficient information about the required calibration interval and maximum sensor drifts has to be acquired from trustful sources such as the manufacturer's data sheet or in-house validations. These drift values then have to be considered in the frame of the entire uncertainty budget. For example, one of the pressure sensors used in HAI (Omega PAA33X-V-1) has long-term stability

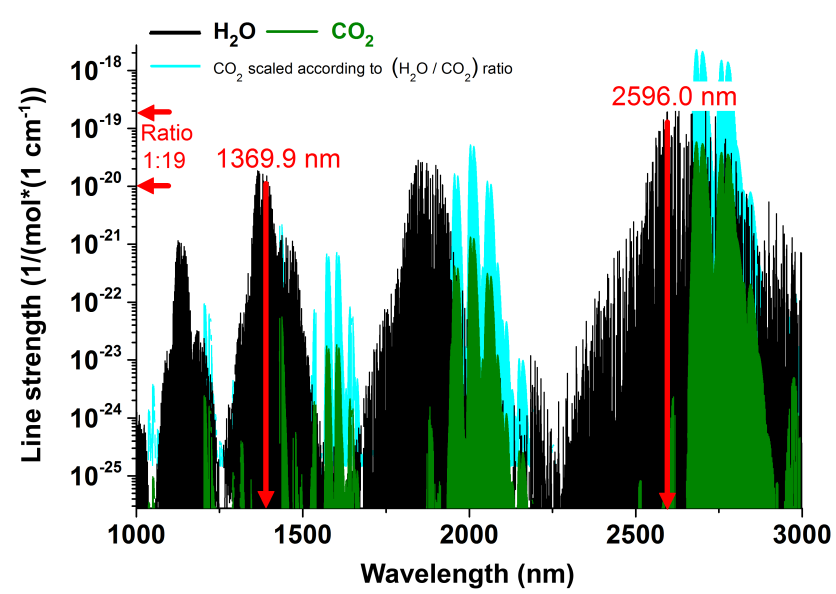

Figure 2. HITRAN 2008 line strength plot (Rothman et al., 2009) for $\mathrm{CO}_{2}$ (green) and $\mathrm{H}_{2} \mathrm{O}$ (black). The turquoise spectrum in the back shows the scaled (factor 39) $\mathrm{CO}_{2}$ line strengths for visualization of the stratospheric situation with a low water vapor content (10 ppmv) and standard $\mathrm{CO}_{2}$ (390 ppmv) level.

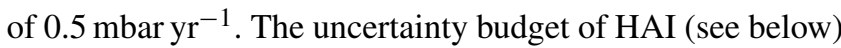
clearly indicates that even if this were 5 times higher it would not require a calibration cycle of less than a year.

The calibration-free approach used in HAI could certainly be enhanced by a calibration of HAI (such as Muecke et al., 1994) at any time (Buchholz et al., 2013b), even after a campaign, if this seems advantageous, since the requirements for a calibrated instrument are lower than for a calibration-free instrument. For a limited time section between two calibration intervals we could therefore improve the accuracy of HAI at the expense of additional time and cost effort for the calibration itself. However, we also would then "downgrade" HAI by making its performance dependent on the availability of a calibration reference and we would also limit this performance "gain" to the time span between two calibrations. In addition, it is also a fact that a calibration only indicates the agreement between the reference and the sensor at the time of the calibration. Additional uncertainty contribution would have to be taken into account for drifts of the instrument in the time span between two calibration points. The many "ifs" related to calibration procedures and the high additional "costs" led us to design and realize an instrument which completely avoids such a process and has a well-defined performance based on a physical first-principle model.

\subsection{Non-calibrated dTDLAS}

The spectroscopic principle of non-calibrated absolute dTDLAS is very briefly presented in the following section. For more detailed information regarding dTDLAS, the reader is referred to the above-mentioned literature. The sketch in Fig. 1 shows the schematics of a dTDLAS spectrometer with two independent channels. For low light intensities $I_{0}(\lambda)$ in the $\mathrm{mW}$ range, the transmitted light $I(\lambda)$ can be described by 
the extended Lambert-Beer equation (Eq. 1), including possible disturbances by background radiation, $E(t)$, or broadband transmission losses, $\operatorname{Tr}(t)$.

$$
\begin{aligned}
I(\lambda) & =E(t)+I_{0}(\lambda) \cdot \operatorname{Tr}(t) \\
& \cdot \exp \left[-S(T) \cdot g\left(\lambda-\lambda_{0}\right) \cdot N \cdot L\right]
\end{aligned}
$$

By applying the ideal gas law, Eq. (1) can be used to retrieve the $\mathrm{H}_{2} \mathrm{O}$ volume mixing ratio $c$.

$c=-\frac{k_{\mathrm{B}} \cdot T}{S(T) \cdot L \cdot p} \int \ln \left(\frac{I(v)-E(t)}{I_{0}(v) \cdot \operatorname{Tr}(t)}\right) \frac{\mathrm{d} v}{\mathrm{~d} t} \mathrm{~d} t$

The amount fraction $c$ is in metrological units officially specified as $[\mathrm{mol} / \mathrm{mol}=\mathrm{mol}$ absorber per $\mathrm{mol}$ gas], which is in the environmental community better known as "volume fraction", for example in units of ppmv or Vol.- \%. The term $\frac{\mathrm{d} v}{\mathrm{~d} t}$ is called the dynamic tuning coefficient of the used laser. It can be determined experimentally and is directly linked to the SI units (length) by using the Airy signal of the laser light passing through a planar, air-spaced etalon (Ebert and Wolfrum, 2000; Schlosser et al., 2002). However, unpublished, on-going, and long-term $\frac{\mathrm{d} v}{\mathrm{~d} t}$ measurements for the $1.37 \mu \mathrm{m}$ distributed feedback (DFB) laser type used over several years indicate a long-term stability of its tuning characteristics better than $1 \%$, which is within the current uncertainties of the tuning characterization. The variable $t$ represents time, $k_{\mathrm{B}}$ is the Boltzmann constant and $L$ is the optical path length. $S(T)$ is the line strength of the selected molecular transition (see chapter below) and therefore a physical property of the molecule to be measured. The gas pressure $(p)$ and gas temperature $(T)$ can be accurately acquired in a closedpath cell $(\mathrm{CPc})$; the quality of the respective measurements in the open-path cell is discussed in the following chapter describing the construction of the open-path sensor. Equation (2) also "explains" the term calibration-free quantitatively as there are no other "hidden" parameters used to derive the water vapor concentration which require a calibration.

\subsection{Absorption line selection}

Suitable absorption lines have to be selected for a specific application by several criteria (Wagner et al., 2012; Wunderle et al., 2006). Besides a line strength maximization to ensure high sensitivity, other important parameters have to be taken into account. For atmospheric measurements, the cross sensitivity to other gases such as $\mathrm{CO}_{2}$ needs to be minimized. This ensures a better control of the fitting process due to the fewer degrees of freedom. Similarly, the line should be isolated from other lines to simplify the retrieval of the baseline function. For the open-path measurements, it is highly important to minimize temperature dependence of the line strength in order to minimize the influence of gas temperature uncertainties. Lastly, sometimes the primary constraint is the availability of suitable laser diodes and additional accessories such as fibers, optic components, lenses, or detectors. As the certification for airborne instruments nearly prevents improvements and repairs during a campaign, all components need to be very reliable. For HAI, we selected two specific water lines at 2596 and $1370 \mathrm{~nm}$. The latter has been used by us and others before (Buchholz et al., 2012, 2013b; Ebert, 2006; Ebert et al., 2004; Fahey and Gao, 2009; Hovde et al., 2001; Hunsmann et al., 2008; May, 1998; Seidel et al., 2012; Witzel et al., 2012; Wunderle et al., 2008) and improved spectral parameters were available (Hunsmann et al., 2006). The $2.6 \mu \mathrm{m}$ laser is not fiber-coupled, does not have an optical isolator, is less stable in terms of temperature fluctuations, and has a lower beam quality, but it accesses a line that is a factor of 20 stronger and thus ultimately promises $20 \times$ higher sensitivity. Both lines are shown (Fig. 2) as a simulation based on the HITRAN (Rothman et al., 2009) database. Assuming an optical resolution of $5 \cdot 10^{-4}$ optical densities (OD), the hygrometer is expected to provide for a $1.4 \mu \mathrm{m}$ CPc (assuming a $1.5 \mathrm{~m}$ path length) under atmospheric conditions a water vapor concentration range from 10 to $40000 \mathrm{ppmv}$ and for the $2.6 \mu \mathrm{m}$ closed-path channel from 0.5 to 5000 ppmv. The lower limit will finally be defined by the capability of minimizing and compensating the effects of parasitic $\mathrm{H}_{2} \mathrm{O}$ offsets (Buchholz and Ebert, 2014b) and their related uncertainties. For the $2.6 \mu \mathrm{m}$ channel, the upper limit depends strongly on the retrieval quality of the baseline. This means, for example, under lower pressure conditions ( $<500 \mathrm{hPa}$ ) evaluations up to $40000 \mathrm{ppmv}$ (similar to $1.4 \mu \mathrm{m}$ ) can be performed. At higher pressures and higher concentrations the absorption line is strongly saturated and such broadened that the baseline cannot be retrieved with a sufficiently low uncertainty. The upper limit in general, i.e., also for the $1.4 \mu \mathrm{m}$ channels, is defined by the dew point related to the instrument temperature; $40000 \mathrm{ppmv}$ is equal to $100 \% \mathrm{RH}$ at $28.5^{\circ} \mathrm{C}$ and $1013 \mathrm{hPa}$.

\section{HAI configuration}

HAI can be installed on an aircraft in several different ways and configurations. This paper focuses on the deployment during the first HALO (Krautstrunk and Giez, 2012) campaigns (TACTS; Engel et al., 2013 and ESMVal; Schlager, 2014), which targeted multiphase $\mathrm{H}_{2} \mathrm{O}$ measurements. Figure 3 (right) shows the fuselage of HALO with the two mountings belonging to HAI. In the very front is a trace gas inlet (TGI), where HAI uses the second opening from the top to sample air in flight. The sampling height is approximately $25 \mathrm{~cm}$ above the aircraft skin. Next to the TGI is the HAI open-path cell $(\mathrm{OPc})$, which is a fiber-coupled, White type three-mirror configuration mounted on two pylons. These mirrors fold the $4.8 \mathrm{~m}$ laser light beam shown in the middle (yellow). Both the TGI and the OPc are installed on HALO specific aperture plates. Figure 3 (left) depicts the 


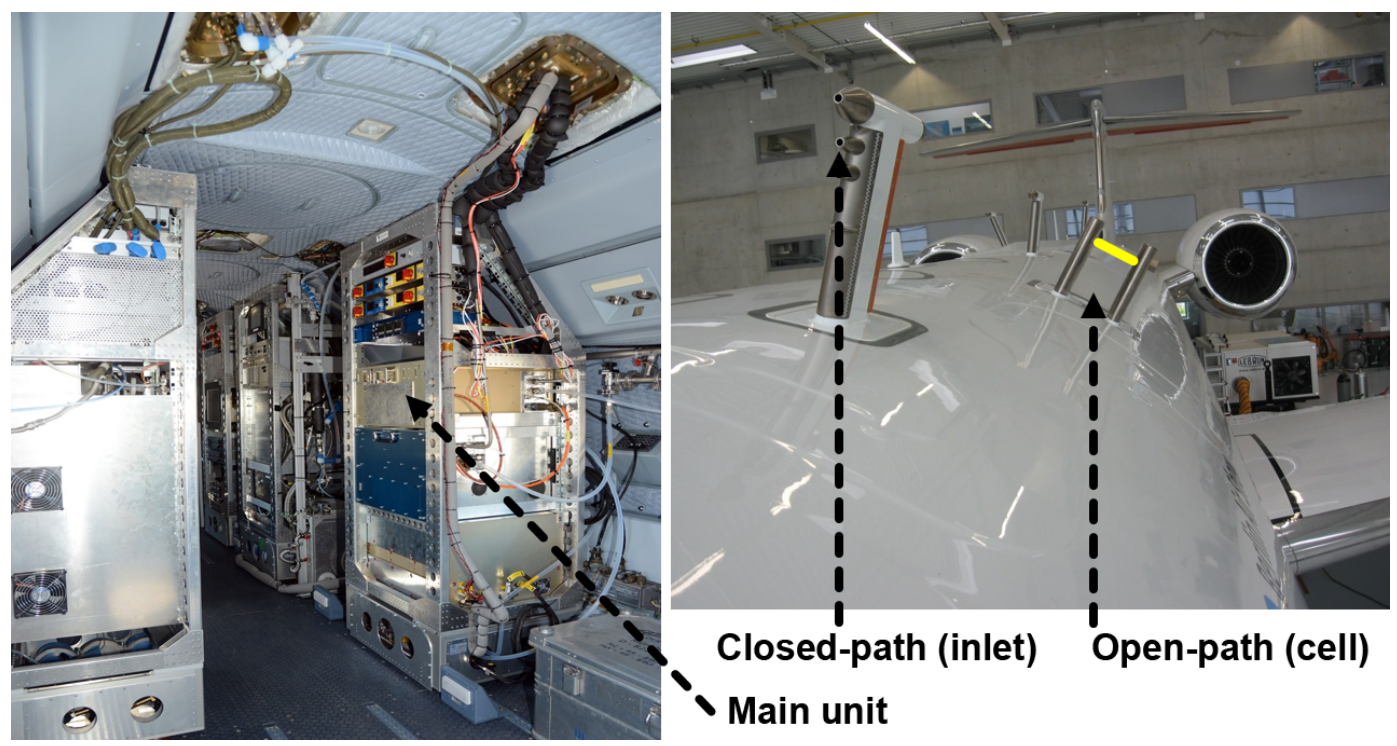

Figure 3. Photos of HALO's cabin layout with installed payload for the TACTS/ESMVal campaign (left). Photo of HALO's fuselage showing the trace gas inlet (TGI) for HAI's closed-path cells (for total water detection) as well as HAI's open-path cell (for gas-phase water detection; open-path laser beams are shown in yellow).

cabin installations with the golden HAI main instrument in the middle. The black insulated half-inch pipes on the right side of the rack are the inlet pipes guiding the air flow sampled by the TGI to the HAI main unit. These electro-polished stainless steel pipes are heated $\left(70^{\circ} \mathrm{C}\right)$ to evaporate ice particles and droplets in the gas stream at a flow rate of approximately 100 volume $\mathrm{L} \mathrm{min}^{-1}$. The open-path sensor is not visible in this photo since it is on the left side of the rack.

\subsection{HAI main unit}

HAI's main unit comprises all laser, electronic, control, etc. modules except for some minor electronics parts of the OPc, which are directly mounted cabin-sidewise on the OPc to minimize noise and electromagnetic irradiation; these components on the OPc comprise low noise preamplifiers for detectors (InGaAs and InGaAsExt), five converters for PT100 temperature sensors, mirror heating controllers $(20 \mathrm{~W}$ per mirror), and two gas pressure sensors. Many of the modules in the HAI main unit contain innovative developments, which are or will be published in subsequent papers to prevent this overview paper from being overloaded with long lists of technical details. The important functions and modules to understand the HAI concept are as follows:

a. automatic line identification and spectral locking to compensate temperature and electrical influences as well as drifts;

b. internal mechanism (Buchholz and Ebert, 2014b) to minimize and compensate effects from parasitic absorption, which usually leads to variable offset problems in spectrometers like HAI; c. gas handling system which tempers the air to be analyzed to the temperature of the instrument and therefore avoids the risk of temperature inhomogeneity even at high gas flows and provides detailed information about temperature, pressure, and gas flow in and through the system;

d. several individual sensors and electronics to collect in total more than 120 system parameters about the HAI system's health - the so-called "housekeeping data";

e. sequence control system for steering, controlling, and exception treatment of HAI with all its submodules.

\subsection{HAI's closed-path cells}

Core parts of the HAI main unit are the extractive, i.e., "closed-path", optical cells (Fig. 4) which are integrated in individual 1.4 and $2.6 \mu \mathrm{m}$ optics modules. The $1.4 \mu \mathrm{m}$ laser is a DFB fiber-coupled diode laser at $1370 \mathrm{~nm}$ from NEL and the $2.6 \mu \mathrm{m}$ diode laser is a DFB diode laser from Nanoplus, which is collimated with a $\mathrm{ZnSe}$ aspheric lens designed by our group. Both optics modules are completely independent. Both CPcs use a new, compact, high numerical aperture miniature White type (White, 1976) design that folds the laser beam (total approximately $1.5 \mathrm{~m}$ ) with three mirrors at approximately $7.5 \mathrm{~cm}$ distance. The $1.4 \mu \mathrm{m}$ cell is an improved, lens-less fiber-coupled version of the White cell described in Kühnreich et al. (2013). It is combined with a new vacuum-tight fiber feedthrough (Buchholz and Ebert, 2014a), which reaches a very low leakage rate of $1.9 \times 10^{-6} \mathrm{hPaL} \mathrm{s}^{-1}$ and prevents parasitic absorption offsets due to ambient air. Three mirrors, one fiber, and one de- 


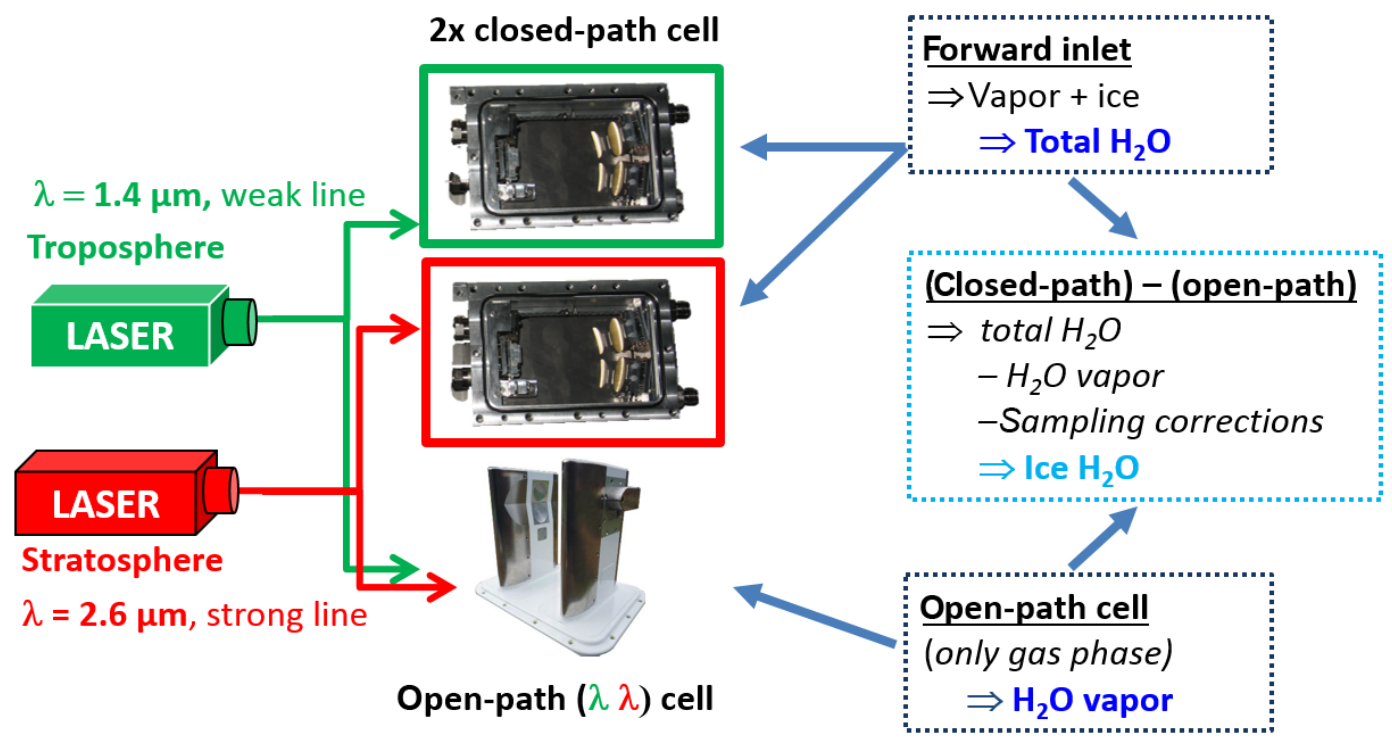

Figure 4. Schematic of HAI's working principle in the multi-phase configuration. By combining selective open-path gas-phase measurements with total water measurements in closed-path extractive cells (ice and droplets are evaporated by heated inlet lines before reaching the cells), it is possible to derive the ice water content from the difference between closed-path and open-path readings.

tector are the only optical parts inside the cell. This reduced amount of optics efficiently minimizes fringing effects down to a long-term $10^{-4}$ optical density signal-to-noise $\left(\mathrm{OD}_{\mathrm{SN}}\right)$ level. No readjustment of the cells was needed or exercised in the approximately 400 flight hours which have been realized over more than 3 years. The temperature is measured via a $3 \mathrm{~mm}^{2}$ accurate $(0.3 \mathrm{~K})$ PT100 sensor for slow temperature changes ( $t_{0.5}$ approximately $\left.2.5 \mathrm{~s}\right)$ in addition to a thermocouple (type T, $0.5 \mathrm{~mm}$ diameter) for faster gas temperature changes $\left(t_{0.5}\right.$ approximately $\left.0.5 \mathrm{~s}\right)$. Due to the abovementioned gas handling system and the thermal mass of the whole instrument (approximately $31 \mathrm{~kg}$ ), temperature fluctuations are measured to be below $0.1 \mathrm{~K}$ during aircraft operation. Each cell has a volume of approximately $300 \mathrm{~cm}$ and is, depending on the installation scenario, typically flushed

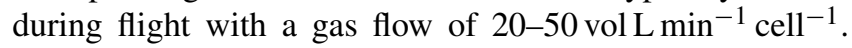
This leads to an approximate exchange time of $0.7 \mathrm{~s}$ by using a "bulk flow" estimation. The $2.6 \mu \mathrm{m}$ closed-path cell is by its design quite similar to the $1.4 \mu \mathrm{m}$. The most significant difference is the free-space beam guidance into the cell. Fibers at $2.6 \mu \mathrm{m}$ are quite critical to handle and a suitable fiber beam splitter was not available when HAI was developed. Therefore, the $2.6 \mu \mathrm{m}$ laser, the reference cell for spectral stabilization, beam splitters, mirrors, and fiber coupling section for the open-path cell are free-space coupled without fibers and enclosed in a specially designed gas-tight $2.6 \mu \mathrm{m}$ optics module box. This module is internally dried by a proprietary purging cycle containing a gas drying system based on the same idea as that used for removing parasitic offsets in fiber-coupled hygrometer (Buchholz and Ebert, 2014b). The $2.6 \mu \mathrm{m}$ closed-path cell is directly coupled to this laser module. Before reaching the cell, the laser beam is therefore "free-space" guided in a water-vapor-free environment (in typical operation $<0.5 \mathrm{ppmv}$ ) for approximately $19 \mathrm{~cm}$. This efficiently avoids parasitic effects in the beam path. The optical-path ratio between closed-path cell and "free-space" area of $7.9(1.5 \mathrm{~m} / 0.19 \mathrm{~m})$ yields in the closed-path $2.6 \mu \mathrm{m}$ cell an offset of less than $0.063 \mathrm{ppmv}(<0.5 \mathrm{ppm} / 7.9)$ to be corrected. The total uncertainty of the offset determination (realized via the so-called "two pressure separation method" (2pS); Buchholz and Ebert, 2014b) amounts to less than 0.4 ppmv, which also defines the lower measurement limit of HAI's $2.6 \mu \mathrm{m}$ channel.

\subsection{HAI's open-path cell}

HAI's open-path cell (Buchholz et al., 2013a), installed in the HALO's fuselage, uses a similar optical White cell concept like the closed-path cells (White, 1976) in HAI's main unit. Contrary to the closed-path cells, both wavelengths (2.6 and $1.4 \mu \mathrm{m}$ ) are simultaneously coupled into a single set of White arranged mirrors via two independent glass fibers for 1.4 and $2.6 \mu \mathrm{m}$. The cell (made of $2 \mathrm{in}$. diameter copper mirrors) has a mirror base distance of approximately $15 \mathrm{~cm}(2 \mathrm{x}$ more than the closed-path cells) and is set to an optical path length of $4.2 \mathrm{~m}$. The optical measurement volume is located approximately $23 \mathrm{~cm}$ above the aircraft skin. The air temperature within the open-path cell is measured via two surfacemounted platinum PT100 sensors. These temperature sensors provide, together with the HALO's temperature measurement (Giez, 2012) and our CFD simulation (to be discussed in a subsequent publication; some preliminary data are in Buchholz, 2014), an estimated $( \pm 5 \mathrm{~K})$ temperature in 
the actual measurement volume of the open-path cell. Improved temperature field simulations will be realized in the future as soon as a full CFD model of the aircraft and HAI is accessible. To prevent a dew or frost buildup on the mirror surface, all three mirrors are individually heated with approximately $20 \mathrm{~W}$ each. This raises the mirror temperature, defined by core temperature measurements inside the copper mirrors, typically $15-20 \mathrm{~K}$ above the ambient temperature. The gas pressure measurements are done by two commercial piezo pressure transmitters. Their individual ports are located on either side of the open-path cell. An in-flight pressure sensor validation has been realized recently via the first optical airborne pressure measurements (Buchholz et al., 2014b). This calibration-free approach exploits the pressure dependence of the collisional broadening of the water absorption line.

\subsection{TDLAS-based multi-phase $\mathrm{H}_{2} \mathrm{O}$ measurements}

By simultaneously performing closed-path and open-path water measurements at high speed, HAI is the first TDLAS hygrometer allowing a calibration-free, synchronous multichannel, multi-phase water detection. The schematic of the HAI configuration is shown in Fig. 4.

Both independent closed-path cells are connected via heated inlet lines (visible in Fig. 3 left) to the forward-facing TGI sampling in clouds gas-phase water vapor and ice particles or $\mathrm{H}_{2} \mathrm{O}$ droplets together. Droplets and ice particles are evaporated in heated inlet pipes, so that both closedpath cells analyze the so-called total water content, i.e., the sum of the interstitial gas-phase water plus the evaporated condensed-phase water. This evaporation step is necessary since the dTDLAS signal is "blind" for direct absorption from condensed water phases. The shifted broad band spectra of condensed-phase and ice-phase water is thus suppressed and dTDLAS is only sensitive to the narrow spectral structure of water vapor. The combination of the narrow absorption line width with the narrow diode laser tuning range allows a very effective discrimination of the broad spectra of ice or liquid water. Depending on the final usage, the total water content has to be further corrected for the particle sampling efficiency of the inlet system impacted by traveling speed, inlet orientation, and other parameters causing an enhancement of certain particle size fractions (overrepresentation of large particles due to their momentum). A detailed sampling characterization and sampling analysis of these HALO inlet (TGI systems) can be found in literature (Krämer and Afchine, 2004).

The open-path cell, directly located on the fuselage of HALO, measures the pure interstitial gas-phase water vapor of the air flowing through the cell. By combining the total water and the gas-phase water measurement, i.e., closed-path and open-path signals, it is possible to derive from the difference of both HAI signals the pure condensed water phase, i.e., the ice or droplet phase. To our knowledge, HAI is the

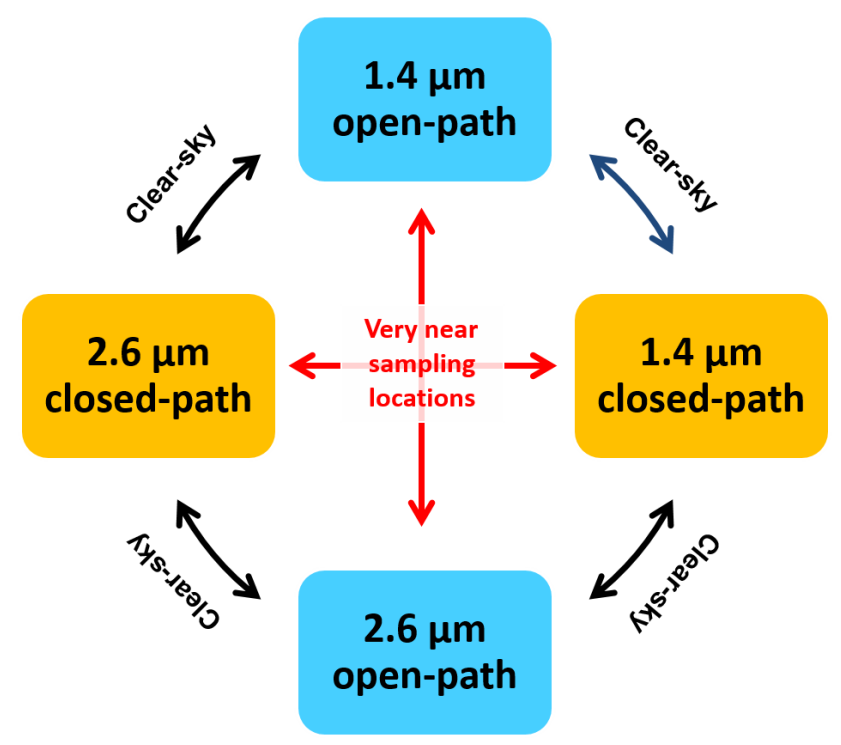

Figure 5. HAI's self-validation possibilities under clear-sky conditions (black) and measurement redundancies under all atmospheric conditions (red). For details see text.

first airborne instrument that can measure all water phases with the same detection principle, the same evaluation strategy, and with two channels, each spectroscopically and temporally linked by one single laser. When independent devices have been used previously to measure these water products, even with similar TDLAS instruments like in Vance et al. (2015), this always led to the discussion on how many of the deviations are caused by atmospheric effects and how many are linked to discrepancies between the participating instruments caused by different characteristics, response times, or nonlinearities of the individual instruments. Indeed, the calibration or even validation of all other open-path hygrometers cited above is based on laboratory measurement or in-flight comparisons with other hygrometers with different properties, making it nearly impossible to justify more than statistical (averaged) statements. Especially in mid-tropospheric regions, small-scale spatial variations of water vapor content lead, at typical HALO cruising speeds, to local temporal gradients of up to $1000 \mathrm{ppmv} \mathrm{s}^{-1}$ in the gas-phase and several $10000 \mathrm{ppmv} \mathrm{s}^{-1}$ in the total water phase. HAI's effective average time of just $1.3 \mathrm{~ms}$ at an output data rate of 120 independent measurements per second allows for the first time a detailed investigation of such structures as well as a very high-temporal-resolution point-by-point comparison of all four spectrometer signals of HAI. Pairwise comparisons of HAI's four channels therefore allow various possibilities for self-validation of the in-flight signals. Further, it is possible to avoid averaged statements and facilitate discrimination/analysis of effects such as sampling artifacts, hysteresis, vibrations, and oscillations. 


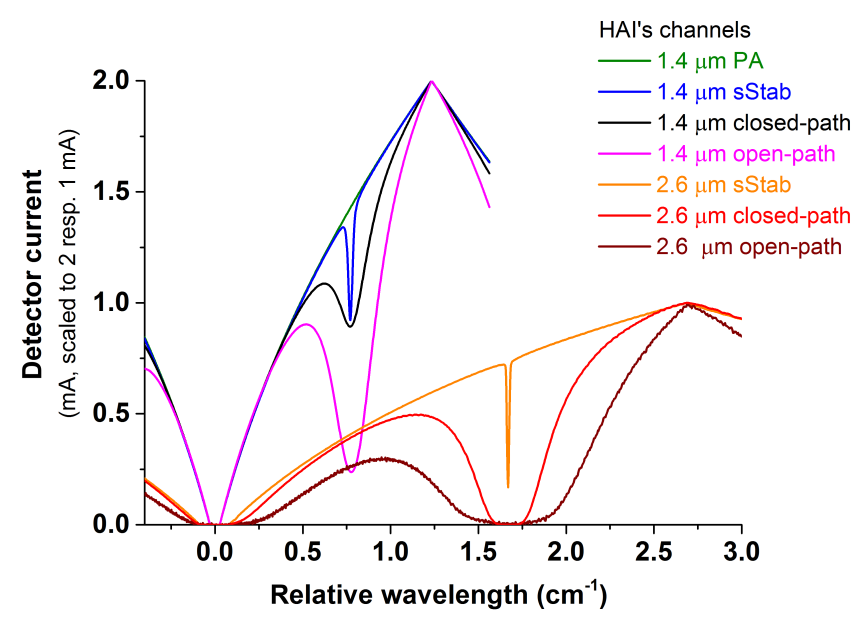

Figure 6. dTDLAS raw signals (spectra) of all seven spectroscopic channels permanently acquired and saved by HAI. The $x$ axis is already converted to the wavelength axis via the individual dynamic tuning rate of each laser. Each spectrum contains approximately 170016 bit values (PA: parasitic absorption; sStab: spectral stabilization).

\subsection{Self-validation}

The new self-validating capabilities are a consequence of the unique $2 \times 2$ multi-channel configuration, which enables six individual validation pathways, as illustrated in Fig. 5. Under clear-sky (cloud-free) conditions, the independent openpath and closed-path measurements should each deliver the same value. Important to note is that both the 1.4 and the $2.6 \mu \mathrm{m}$ spectrometer channels are evaluated without common parameters in calibration-free (first-principle) mode. This means, in detail, two different lasers, two different absorption paths, two different absorption lines, different line parameters, different electronics, different gas pressure/temperature sensors, etc. Nevertheless, both spectrometer channels have to agree within their uncertainty if the first-principle evaluation is applicable. Due to the large overlapping $\mathrm{H}_{2} \mathrm{O}$ concentration range of approximately 50 to $5000 \mathrm{ppmv}$, all disturbances can be clearly identified as long as they affect both spectrometers differently. Outside of clouds (clear-sky) - i.e., in ice-particle-free and water-droplet-free air - all four spectrometer channels have to agree. This in particular allows us to validate (or even if necessary to calibrate) the closed-path cells in a laboratory environment and to use them as an airborne transfer standard to validate or even calibrate in turn the open-path sensor in flight. This is a unique property of HAI, since each open- and closed-path spectrometer is coupled by one single laser and all four spectrometers employ the same evaluation procedure. Hence, $\mathrm{HAI}$ is called a $2 \times 2$ spectrometer.

\section{Results}

\subsection{Signal assessment}

Figure 6 shows - at the same instant of time - all seven raw optical signals from HAI's measurement channels at approximately $15000 \mathrm{ppmv}$ and $900 \mathrm{hPa}$. For visualization, the signals of each laser are scaled to the same peak maximum, since transmission changes are irrelevant according to the equation for concentration retrieval (Eq. 2). The time axis ( $240 \mathrm{~Hz}$ laser repetition rate) is already converted to the wavelength axis using the dynamic tuning rate. The triangular modulation of the diode laser current yields a triangular modulation of the beam intensity and a similar shape in the wavelength space. The tuning range of the $2.6 \mu \mathrm{m}$ laser is set to be broader in order to allow the evaluation of high absorbance spectra when the peak absorption is in saturation in the absorption line center. The Lorentzian line wings still carry enough information to retrieve the concentration. The absorbance of the open-path signal (e.g., the $1.4 \mu \mathrm{m}$ signal in purple) is higher than the one from the closed-path cell due to the 3-fold longer optical path length in the open-path cell. The $1.4 \mu \mathrm{m}$ reference cell signal (blue) is used for spectral stabilization and acquired from a low pressure (approximately $20 \mathrm{hPa}$ ) fiber-coupled reference cell. The signal for retrieving and compensating parasitic absorption is shown in green and the associated evaluation is described in Buchholz and Ebert (2014b). Accordingly, the three $2.6 \mu \mathrm{m}$ signals are shown. The parasitic absorption compensation of the $2.6 \mu \mathrm{m}$ system is due to the "free-space" signal in the sealed laser module (see description above) and is at least as important as the one for the $1.4 \mu \mathrm{m}$ spectrometer. This compensation treatment is done by using an ultra-low pressure (approximately $0.5 \mathrm{hPa}$ ) pure water reference cell which provides information for both the spectral stabilization and the parasitic absorption correction. The latter approach is the $2 \mathrm{pS}$ in Buchholz and Ebert (2014b). The exact gas pressure or gas matrix in the reference cells is irrelevant as we use the cell for line locking but not for concentration calibration as other TDLAS instruments do. The requirement for such a cell is that it contains a sufficiently high water vapor content to ensure a sufficiently high $S / N \mathrm{H}_{2} \mathrm{O}$ absorption signal. The temperatures of both reference cells are accurately measured (PT100 sensor) to monitor the gas pressure increase in the reference cell caused by the temperature rise. This pressure rise induces a significant, measurable shift of the absorption line position, which needs to be corrected to achieve a very high line stabilization quality. The retrieved line position thus is corrected for this shift based on the measured temperature and the known pressure shift coefficient of the absorption line.

Figures 7 and 8 show four typical absorption signals in flight with a pre-average of 50 raw measurements recorded at $240 \mathrm{~Hz}$. This leads to 4.8 measurements per second. In flight situations similar to that, only approximately one-sixths of the whole (up- and down-ramp) spectral scan contains sig- 

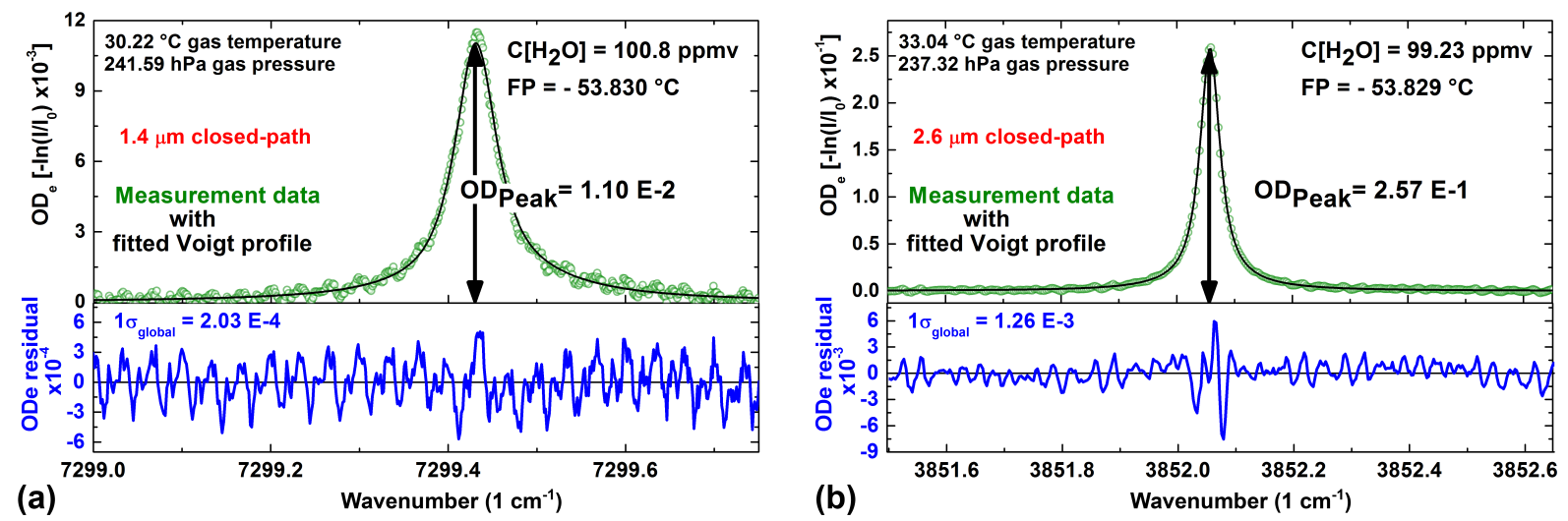

Figure 7. Typical pre-processed absorption signals (after baseline, offset, and transmission correction) for both closed-path spectrometer channels (left: $1.4 \mu \mathrm{m}$; right: $2.6 \mu \mathrm{m}$ ) during flight. The laser modulation frequency was $240 \mathrm{~Hz}$. Fifty individual raw scans are pre-averaged yielding $4.8 \mathrm{H}_{2} \mathrm{O}$ measurements per second with $69 \mathrm{~ms}$ total integration time. This corresponds to a spatial resolution of $15 \mathrm{~m}$ at $800 \mathrm{~km} \mathrm{~h}^{-1}$ cruising speed. Without averaging, HAI achieves a maximum time resolution of $1.3 \mathrm{~ms}$ at a spatial resolution of $30 \mathrm{~cm}^{2} 800 \mathrm{~km} \mathrm{~h}-1 \mathrm{cruising}^{-}$ speed. (It should be noted that the four vertical axes have different scales.)

nificant contributions of the water vapor absorption line (the pressure broadened target absorption line). The "rest" of the wavelength scan is used to retrieve the baseline and the laserout region and used for situations where gas pressure and water vapor concentrations are much higher (e.g., low flights in warm areas, especially in clouds). This small section with the narrow absorption line can thus be interpreted as the "effective" water measurement interval, which could then be interpreted as an effective time resolution (after averaging) of $70 \mathrm{~ms}$ for each reading $(1 / 240 \times 1 / 6 \times 50)$.

Figure 7 allows the simultaneous comparison of both closed-path cells. Gas pressure and temperature are slightly different due to the different piping and installation placement inside of HAI. Both $\mathrm{H}_{2} \mathrm{O}$ concentrations agree $(\Delta=1.6 \%)$ within the combined uncertainties $(7.9 \%)$ of both channels $(4.3 \%$ and $5.9 \%)$. Each graph in Fig. 7 shows in the top the measured data (green dots) with the fitted Voigt profile (black line). The measurement data are shown as absorbance $\left(\mathrm{ODe}=-\ln \left(\mathrm{I} / I_{0}\right)\right)$ values, i.e., the detector $(I)$ signal divided by the so-called "base line" $\left(I_{0}\right)$. The baseline resembles the absorption spectrum in the absence of the molecular target absorption. It is retrieved from the raw spectrum (I) by applying a synchronous polynomial fit of the baseline and a Voigt profile for the absorption line. The residuals between measured data and the model function are depicted below. The remaining structures visible in the residual are optical interference fringes, caused by light scattered from imperfect mirrors, fiber surface, detector arrangement, and wall backscattering. The frequency of a fringe can be linked to the optical distances between the interfering surfaces. So far, these baseline structures as well as the cell alignment remained stable and the mirrors have never required any cleaning during the last 4 years.
"Stability" always has to be related to the right timing context: calibration-free dTDLAS are usually operated at relatively moderate OD resolution levels (of about $>10^{-3}$ ). Otherwise impacts which affect the long-term stability cannot be controlled or assessed well enough. However, in the context of "short-term" precision statements the residual structures only have to be stable on the order of minutes instead of years. The entire fringe structures displayed in the pictures above are phase shifted by temperature due to mechanical expansion of the cell structure. However, the thermal mass of the cells prevents fast temperature changes, which leads to very stable "short-term" fringes down to the $10^{-5}$ OD levels.

This is a crucial point compared to WMS systems, where fringe levels have to be controlled down to the $10^{-6}$ OD level to achieve the sensitivity advantages WMS is known for. Our calibration-free dTDLAS evaluation is designed to require a stable baseline only in the $10^{-4}$ OD range, which makes it inherently robust and improves the stability of the entire system. In other words, dTDLAS systems like HAI are usually not as sensitive to misalignments, dirt, or optical interfering structures as WMS systems but require higher absorbance (higher line strength or longer path length) to allow an implementation of our calibration-free approach.

Figure 8 shows a simultaneous comparison between the open-path and the closed-path channels. The outside gas temperature in the open-path cell is approximately $52 \mathrm{~K}$ lower than in the closed-path cell. The gas pressure in the closedpath cell is much higher than in the open-path cell due to the ram pressure guiding the air through the TGI and piping. The measured water vapor concentrations are slightly shifted in time due to the gas transport and the sampling delay in the pipes. The $1 \sigma$ residual is a factor of 6 higher in the open-path than in the closed-path sensor. This mainly results from the high wind speed through the open-path cell (approximately 

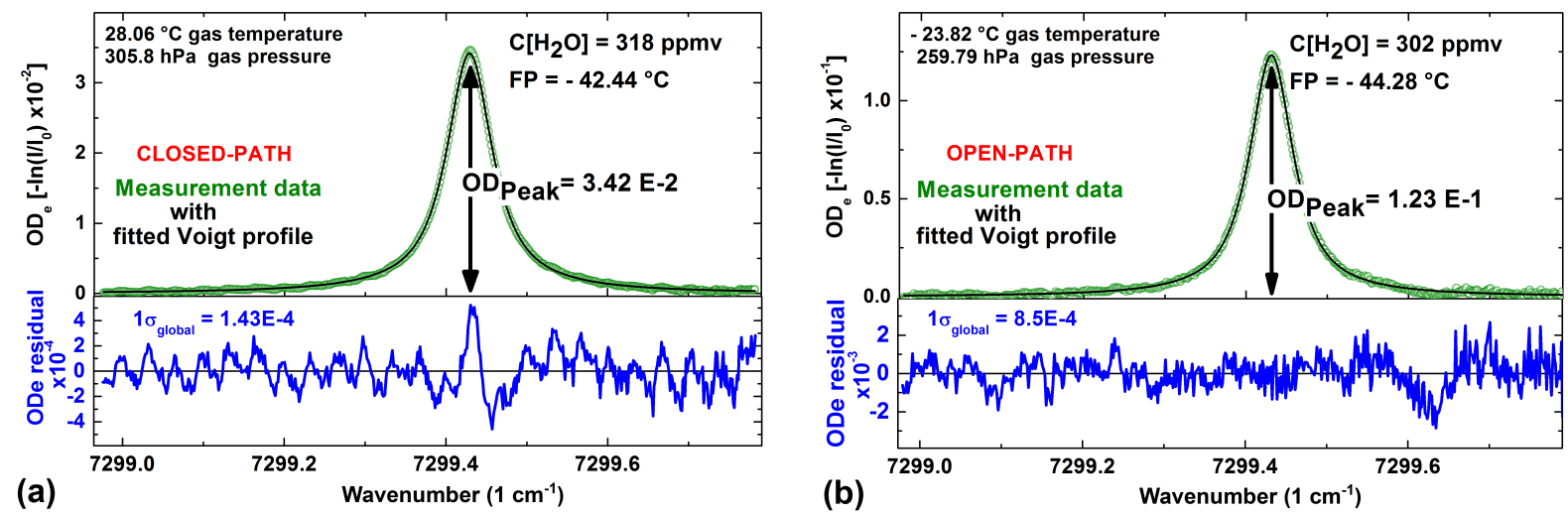

Figure 8. Comparison of pre-processed TDLAS scans (similar to Fig. 7) of HAI's $1.4 \mu \mathrm{m}$ closed-path (left) and the $1.4 \mu \mathrm{m}$ open-path (right) cell during a HALO flight. Despite the entirely different measurement conditions such as wind speed (cm s ${ }^{-1}$ to $100 \mathrm{~m} \mathrm{~s}^{-1}$ ) or temperature $\left(+28\right.$ to $\left.-23{ }^{\circ} \mathrm{C}\right)$, both channels are evaluated calibration-free with the exact same methods and model.

$800 \mathrm{~km} \mathrm{~h}^{-1}$ ), vibrations, and the thermal mass of the closedpath cell as mentioned above.

It is important to mention that for typical diode laser instruments (direct as well as WMS) a change of gas temperature, pressure, and concentration over a large range can cause large systematic offsets, which frequently require at least a three dimensional calibration procedure (including pressure, temperature, and concentration dependence) or the integration of complex assumptions (Duffin et al., 2007; Goldenstein et al., 2014; Rieker et al., 2009) to correct the data via a simulation model. WMS closed-path systems usually avoid this problem by always keeping gas temperature and pressure as close and constant as possible to the calibrated level, which is obviously not a viable approach for an open-path system.

\subsection{Precision}

One common figure of merit to quantify the short-term optical precision of a spectrometer is the $1 \sigma$ noise level in the residuum. The idea is based on the assumption that the residual is governed by random noise, which limits the precision of the system. The signal-to-noise ratio (SNR) is

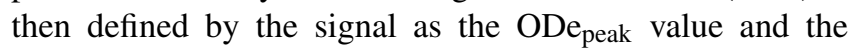
noise as the statistical standard deviation of the residual and

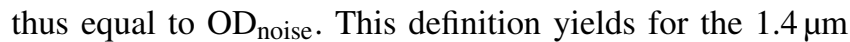
$(2.6 \mu \mathrm{m})$ closed-path cells at $4.8 \mathrm{~Hz}$ time resolution a SNR of 54 (204). The corresponding precision is then $100 / 54 \mathrm{ppmv}$ $=1.9 \mathrm{ppmv}$ (at $1.4 \mu \mathrm{m}$ ) and $100 / 204 \mathrm{ppmv}=0.49 \mathrm{ppmv}$ (at $2.6 \mu \mathrm{m})$. This determination is quite consistent with Fig. 8, where the precision of the $1.4 \mu \mathrm{m}$ closed-path can be estimated to $1.3 \mathrm{ppmv}$ in the same way. However, as the fringe structure of the closed-path cell is, as discussed earlier, quite stable, it is better to determine the instrument precision via the Allan variance (Allan, 1966). Figure 9 shows the Allan plot for both closed-path cells. The measurement was done at 255 ppmv by measuring gas from a big vessel. Un- der these conditions, the precision at $4.8 \mathrm{~Hz}$ is $0.22 \mathrm{ppmv}$ (for the $1.4 \mu \mathrm{m}$ closed-path cell) and $0.065 \mathrm{ppmv}$ ( $2.6 \mu \mathrm{m}$ closedpath cell). Both values are approximately a factor of 8 lower than the one derived from the single scan analysis, which confirms the stability thesis for these kinds of fringes. Vice versa we can derive an actual (unstable, random) $1 \sigma$ residual OD noise level of $2.3 \times 10^{-5}$ for the $1.4 \mu \mathrm{m}$ closed-path and $1.7 \times 10^{-4} \mathrm{ppmv}$ for the $2.6 \mu \mathrm{m}$ closed-path cell. The best precision is achieved at $3.9 \mathrm{~Hz}(0.18 \mathrm{ppmv})$ for the $1.4 \mu \mathrm{m}$ cell and at $13 \mathrm{~Hz}(0.055 \mathrm{ppmv})$ for the $2.6 \mu \mathrm{m}$ cell. Normalizing this with respect to time resolution and optical path length yields a $1 \sigma$ precision of $187(1.4 \mu \mathrm{m})$ and $31 \mathrm{ppbv} \mathrm{m} \mathrm{Hz}^{-1 / 2}$ $(2.6 \mu \mathrm{m})$.

Comparing that precision ratio of 6 between the 1.4 and the $2.6 \mu \mathrm{m}$ to the ratio in line strength of 20 (see line selection Sect. 3.3) confirms the statement mentioned above that drawbacks of the longer wavelength technology significantly constrain the practically achievable maximum gain.

For the open-path sensor, we have not yet been able to calculate an Allan variance so far, since we have not acquired a dataset in flight where the atmospheric water was constant enough not to dominate the Allan variance via natural $\mathrm{H}_{2} \mathrm{O}$ fluctuations. However, using the short-term single spectrum evaluation method in Fig. 8 yields a SNR of 145 for the $1.4 \mu \mathrm{m}$ path, which leads to a precision of $2.1 \mathrm{ppmv}$ (4.6 ppmv m Hz${ }^{-1 / 2}$ ).

\subsection{Uncertainty consideration}

One of the major benefits of the dTDLAS evaluation done with HAI is the high level of control over the fitting and evaluation process. In particular, combining it with the complete storage of all raw data allows a dedicated and highly flexible post-flight analysis or post-flight processing. Raw data storage for HAI covers not only all raw spectra but also approximately 120 measured parameters depicting the complete status of the HAI instrument. This "housekeeping data", 
for example, encompasses 15 temperature measurements that enable diagnostic statements, for example about temperature inhomogeneity, electronic drift, or sensor malfunctions. Housekeeping data like these facilitate assignments of a measurement uncertainty closer to the one in a metrological sense (Joint Committee for Guides in Metrology (JCGM), 2008). If measurements are done in harsh environments or under rapidly changing conditions, typical concepts of metrological uncertainty assessments fall short since most of their concepts are developed for laboratory applications under quasistatic conditions. However, even in this case the housekeeping parameters provide information for a trustful uncertainty consideration. The uncertainty calculations below are based on a physical model (Eq. 2) and performed with an approach independent from the actual measurement. Depending on the individual science community, these uncertainties, errors, reproducibility, or misreading are often determined by comparing the readings of an instrument to reference instrument. This is contrary to a metrological uncertainty and furthermore a nonindependent approach; we therefore call that simply deviation or standard deviation.

According to the Eq. (2) for retrieving the final concentration, the individual contributions to the total uncertainty budget can be assessed as followed for both closed-path cells. The optical path length was primarily determined with a Zemax-based ray tracing simulation. In addition, it was calculated by the mechanical mirror distance and compared to a test measurement with a known amount of $\mathrm{CH}_{4}$ gas in the cell. These measurements lead to an uncertainty of the optical path length of $15 \mathrm{~mm}(1.1 \%)$. The uncertainty for the used $\mathrm{H}_{2} \mathrm{O}$ absorption line strength is $3.5 \%$ [44]. The temperature sensors (PT100 and thermocouple type E as described above) are calibrated against metrological transfer standards (Rosemount platinum resistance thermometer type 162CE (PRT-25), uncertainty $1.5 \mathrm{mK}$ ). Due to the well-known fact that temperature measurements in moving gases suffer from many issues, we use a conservative estimation of $1 \mathrm{~K}(0.3 \%)$. The manufacturer of the pressure sensors (Omega PAA33X) advertises a resolution of $0.02 \mathrm{hPa}$ and a long-term accuracy of $0.5 \mathrm{hPa}$. We use $1 \mathrm{hPa}$ as a conservative uncertainty estimation. A general statement for the laser tuning uncertainty is difficult in a metrological sense, since it depends on local effects in the spectra, pressure range, concentration level, and number of absorption lines fitted. From our experience, we assume that deviations related to the fitting process in total (tuning + fit process) are in the range of below $1.5 \%$ for situations similar to Fig. 6 (note that our calibration-free dTDLAS systems are usually designed to work in the $>10^{-3}$ OD level, where a clear signal assessment is feasible). As a conservative approximation we use $2 \%$ for the fit and $1 \%$ for the tuning. This yields to a total uncertainty of $4.3 \%$ for the $1.4 \mu \mathrm{m}$ closed-path cell.

The largest relative influence to this total uncertainty budget results from the line strength $(66 \%)$, followed by the fitting uncertainty $(21 \%)$, as well as the optical path length
(7\%). Additionally, the offset uncertainty is defined in a calibration-free dTDLAS system by the capability of minimizing and quantifying parasitic offset effects. It is \pm 3 ppmv for the $1.4 \mu \mathrm{m}$ closed-path cell of HAI, which uses the same parasitic prevention treatment as SEALDH-II (Buchholz and Ebert, 2014b). Thus, the total uncertainty of the $1.4 \mu \mathrm{m}$ closed-path system is $4.3 \% \pm 3$ ppmv. Similar considerations lead to an uncertainty of $5.9 \% \pm 0.4 \mathrm{ppmv}$ for the 2.6 $\mu$ m closed-path cell.

Related to the open-path cell, similar uncertainty statements are more difficult. First of all, a full CFD model of the boundary layer around HALO is currently missing, which would allow a retrieval of the gas temperature in the openpath cell. The first CFD test runs of HAI's open-path sensor and its immediate surroundings have been realized (A. Afchine (FZJ), published in Klostermann, 2011), and they led to a first temperature uncertainty estimate of $\pm 7 \mathrm{~K}$. The full CFD model could also provide pressure field calculations. However, in this case, we developed a method to retrieve the pressure directly from the dTDLAS signal (Buchholz et al., $2014 b$ ) and use that for a validation of the built-in micromechanical pressure sensor. The pressure dependent uncertainty is in the range of $3-5 \%$. The uncertainty of the fitting process reveals a much higher complexity. It depends on all impacts on the spectral signal itself, such as background radiation on the detector, misalignment due to the distortion of the HALO fuselage, forming of an ice layer on the mirrors, high optical dense cloud transects, and eddies around the aircraft. From all the data gathered and compared during the HALO missions TACTS and ESMVal, we could not find any deviation larger than $\pm 5 \%$ in clear-sky conditions between the open-path and the closed-path sensor which could not be clearly linked to explainable effects. Besides the availability of an entire CFD model in the future, HAI will be validated by sampling the pure water vapor gas phase with its closedpath cells (connected to backward-facing TGI measurement) in future campaigns. These datasets will sustainably prove whether the $\pm 5 \%$ deviation is valid under all conditions, since all four channels of HAI (Fig. 5) should permanently measure then the same atmospheric value. Compared to the deviations, revealed in the AquaVIT (Fahey et al., 2014) comparison of state-of-the-art airborne hygrometers in 2007 , this $5 \%$ is 4 -fold smaller than the span $(20 \%)$ of those instruments there. Additionally, one has to keep in mind that this AquaVIT comparison was done under quasi-static laboratory conditions. Therefore, this in-flight $5 \%$ deviation between the open-path and the closed-path sensor shows the great performance of HAI, even if a general metrological uncertainty is difficult to be given at this time.

\subsection{First airborne measurements with HAI on the HALO aircraft}

Figure 10 shows typical HAI measurements during the first HALO science mission "TACTS/ESMVal". The cho- 


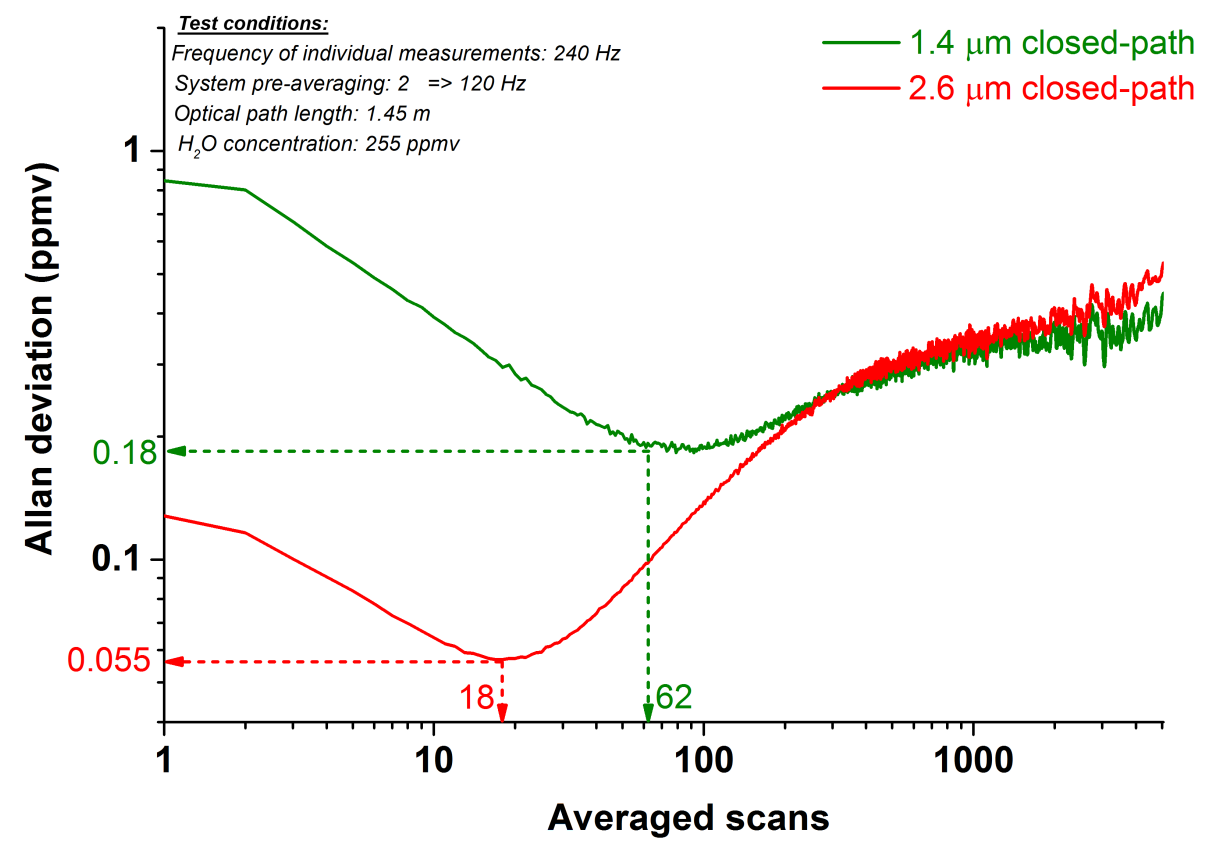

Figure 9. Allan variance plots for both closed-path spectrometer channels. The measurements were done by analyzing gas from a big buffer vessel with a $\mathrm{H}_{2} \mathrm{O}$ concentration of $255 \mathrm{ppmv}$. The optimal precision at $4.8 \mathrm{~Hz}$ derived from this measurement is $0.22 \mathrm{ppmv}$ for the $1.4 \mu \mathrm{m}$ closed-path cell and $0.065 \mathrm{ppmv}$ for the $2.6 \mu \mathrm{m}$ closed-path cell. The best - i.e., highest - precision of $0.18 \mathrm{ppmv}$ is achieved at $3.8 \mathrm{~Hz}$ for the $1.4 \mu \mathrm{m}$ cell and $0.055 \mathrm{ppmv}$ at $13 \mathrm{~Hz}$ for the $2.6 \mu \mathrm{m}$ cell.

sen flight profile shows 15 min of a slow ascent from the lower to the upper troposphere. Depicted in Fig. 10 are the $\mathrm{H}_{2} \mathrm{O}$ concentration measured with the $1.4 \mu \mathrm{m}$ CPc (black), the $1.4 \mu \mathrm{m}$ OPc (magenta), and the $2.6 \mu \mathrm{m} \mathrm{CPc} \mathrm{(red)} \mathrm{channel}$ of HAI (left axis) as well as the ambient gas pressure (right $y$ axis, in blue), which is directly connected to the flight level (height). The green dotted line shows the water vapor saturation mixing ratio (SMR) calculated from the static ambient temperature and pressure measured by the HALO avionic system (Giez, 2012). The SMR indicates that HALO flew in the early part of the flight (left) in clear-sky conditions (no clouds) and in the second part of the flight though cirrus clouds. All Fig. 10 data were plotted with $1 \mathrm{~Hz}$ temporal resolution. With increasing height, the $\mathrm{H}_{2} \mathrm{O}$ concentration declines about 2.5 orders of magnitude from approximately 2000 to $75 \mathrm{ppmv}$, in combination with simultaneous relative pressure variation from approximately 175 to $450 \mathrm{hPa}(\Delta p=275 \mathrm{hPa})$. The $\mathrm{H}_{2} \mathrm{O}$ concentrations, measured with HAI's two independent closed-path spectrometer channels, fit nicely to each other and show only a small average relative deviation of $1.9 \%$ (bottom graph in red), which is entirely covered by the uncertainty range of each spectrometer (4.3 resp. $5.9 \%$ ). This result is consistent with other measurements, where the $2.6 \mu \mathrm{m}$ path was persistently on average approximately $2 \%$ higher than the $1.4 \mu \mathrm{m}$ channel. This could be easily explained with the $2.6 \mu \mathrm{m}$ line strength from the HITRAN database being $2 \%$ too small. The $1.9 \%$ deviation also needs to be related to the fact that both hygrome- ter channels are evaluated completely independently, without any calibration of the instrument and most importantly under real-world flight conditions. Despite these demanding conditions, HAI's two closed-path channels generate a relative deviation which is just one-tenths of the above-mentioned $20 \%$ in AquaVIT (Fahey et al., 2014), which demonstrates the excellent accuracy of the HAI spectrometers.

The purple signal in Fig. 10 shows the measurement of the $1.4 \mu \mathrm{m}$ open-path sensor $(1.4 \mu \mathrm{m}$ OPc $)$. Compared to the $1.4 \mu \mathrm{m}$ closed-path cell $(1.4 \mu \mathrm{m} \mathrm{CPc})$, the $1.4 \mu \mathrm{m}$ OPc shows a relative deviation of $\pm 5 \%$ peak-to-peak or $2 \%$ on average. Even though this performance seems good in comparison with the AquaVIT results, a more suitable literature reference would be one with in-flight open-path measurements rather than quasi-static laboratory comparisons. However, there is none like that and therefore a "state of the art" statement is quite difficult. This holds especially when we consider the fact that the "uncertainties" or "errors" stated for the other the AquaVIT participants were claimed to be on such a low level that they did not cover or explain the deviations observed. This is strongly correlated to different and nonstandardized definitions, procedures on how to calculate sensor accuracy, and other performance figures yielding often a systematic underestimation of uncertainties compared to metrological procedures such as JCGM (2008) and Joint Committee for Guides in Metrology (2009).

However, a short incomprehensive overview on the performance of previous and current open-path instruments should 

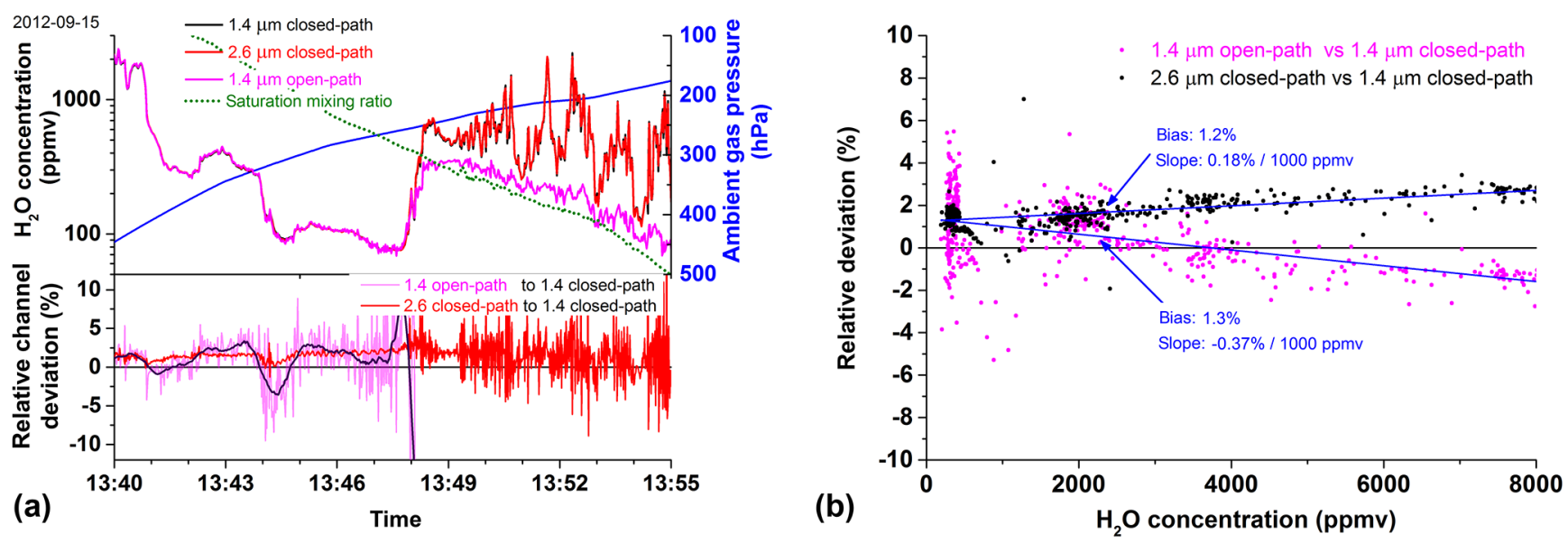

Figure 10. HAI measurement on board HALO during the TACTS/ESMVal campaign. Left: the flight profile shows a 15 min section of a slow ascent from the lower troposphere to the upper troposphere. The first part (under clear-sky condition) can be used to perform an absolute in-flight accuracy comparison of HAI's measurement channels; the second part demonstrates a multi-phase $\mathrm{H}_{2} \mathrm{O}$ measurement. For further explanations of all signals and visible effects, see text. Right: the scatterplot displays on the $x$ axis the water vapor concentration measured by the $2.6 \mu \mathrm{m}$ closed-path cell and on the $y$ axis the relative deviation of the $1.4 \mu \mathrm{m}$ closed-path cell (and the $1.4 \mu \mathrm{m}$ open-path cell) from the $2.6 \mu \mathrm{m}$ closed-path cell measurements. This scatterplot contains all data from 13:40 to 13:48 shown in the left graph.

be given here to compare HAI with their claimed accuracy level:

a. A calibrated, $1 \mathrm{~m}$ direct absorption, open-path sensor at $1.4 \mu \mathrm{m}$ was developed in a feasibility study for the Strato $2 \mathrm{C}$ research aircraft and described to cover a concentration range of 2-2000 ppmv with $100 \mathrm{ppbv}$ precision at $1 \mathrm{~Hz}$. It was claimed to have an accuracy of $5 \%$, but this hygrometer never flew (Roths and Busen, 1996).

b. A calibrated open-path sensor with an optical path length of $375 \mathrm{~cm}$, was folded in a Herriott cell, and a time resolution of $25 \mathrm{~Hz}$ has a precision of $80 \mathrm{ppbv}$. This instrument is designed for the American HIAPER aircraft, a Gulfstream 500 similar to the HALO aircraft. Typical deviations to other instruments were in the range between 2 and $10 \%$ (Zondlo et al., 2010).

c. A calibrated, Herriott cell-based open-path hygrometer with a total path length of $11 \mathrm{~m}$, a measurement frequency up to $10 \mathrm{~Hz}$, and a precision of $50 \mathrm{ppbv}$ at $0.5 \mathrm{~Hz}$ claims to have an uncertainty of 5 to $10 \%$ (May, 1998).

d. An innovative concept was deployed by Diskin et al. (2002). The spectrometer's (2f, calibrated) hardware is attached from the inside of the cabin to a window. The laser beam hits a retro reflector mounted on the outer engines under the airfoil. The total absorption path is $28.5 \mathrm{~m}$; the measurements frequency is $1 \mathrm{~Hz}$; a $1 \sigma$ error is claimed to be $3.7 \%$ (Podolske et al., 2003). Measurements published in Diskin et al. (2002) show deviations of the same order.

In summary, HAI's $2 \%$ deviation appears to be better or at least equal to typical statements in publications but is based for the first time on a meteorologically evaluated, calibrationfree approach.

To further evaluate the performance of HAI's open-path channels we discuss some of the TACTS data. The dark purple line shows the data after smoothing with a $60 \mathrm{~s}$ sliding window algorithm. Quite interesting are the two dents at 13:41 and 13:44 in the relative deviation, which means the closed-path measurement was higher than the open-path measurement. Both of them happened after the water vapor concentration dropped sharply. Hence, the dents might be explained by desorption processes inside of the TGI, its piping, and the measurement cell. This idea is backed by the 1.4 to $2.6 \mu \mathrm{m}$ closed-path comparison (red). The same behavior is also visible at $13: 44$, but here the $2.6 \mu \mathrm{m}$ closed-path cell added less desorption water to the gas steam than the $1.4 \mu \mathrm{m}$ one. Another influence leading to that deviation could be a temperature measurement on HALO affected by fast changes of humidity. The total temperature influence in Eq. (2) is at this temperature and pressure approximately $0.6 \% \mathrm{~K}^{-1}$ caused by the temperature influence via the ideal gas law, the line strength temperature dependence, and the Gaussian width. Other major influences can be excluded since all relevant housekeeping data clearly indicate that HAI operated as expected during the entire time period. The final distinction of small local effects like that can be done by acquiring more flight data in the troposphere for a better understanding of the sampling system. This is planned to be realized in a future campaign more oriented towards the mid-troposphere.

This case study and analysis of HAI's capabilities and performance demonstrates the unique opportunities offered by HAI, which allows a deep analysis to identify and eventually classify different measurement sections of a flight in order to 
distinguish instrumental artifacts from real atmospheric situations.

During the second part of the flight shown in Fig. 10, the aircraft flew through ice clouds (cirrus; temperature $<-40^{\circ} \mathrm{C}$ ). The evaporation of the ice crystals captured by the gas inlet leads to a clear enhancement of the amount of water vapor in the closed-path cells. The relative comparison shows a $\pm 5 \%$ noisy structure, which is caused by the low time resolution of just $1 \mathrm{~Hz} . \mathrm{H}_{2} \mathrm{O}$ gradients in this particular part of the flight are in the range of several $1000 \mathrm{ppmv} \mathrm{s}^{-1}$. Due to SSD hard drive space limitations in the first campaign, only parts of the flights were sampled with the highest time resolution of $240 \mathrm{~Hz}$; other parts were pre-averaged online. Like in the clear-sky region, the average deviation between both closed-path cells during cirrus cloud transects remains at $2 \%$. To further check the accuracy of the open-path channel, we use two methods. The first is based on the physical argument that the gas-phase measurement always has to be lower than the total water measurement, which consists of gas-phase plus evaporated ice or liquid phase. This requirement is entirely fulfilled. The second check compares the absolute gas-phase measurement with the SMR. In the case of a fully equilibrated cloud, the gas phase has to be saturated at temperature $T$, meaning that the relative humidity is $\mathrm{rH}=100 \%$, from which we can derive the SMR with the help of the water vapor partial pressure curve. This is a weaker check, since it is a well-known fact that supersaturation can occur during strong air updrafts.

The transition region at the edge of the cloud is also very interesting, where the closed-path cell sees an enhancement while still being below the SMR. This means that the fringe of the cloud was not saturated but had sublimating ice particles in it.

The data between 13:40 and 13:48 of Fig. 10 right are plotted in Fig. 10 left in a different way: the $x$ axis shows the water vapor concentration measured by the $2.6 \mu \mathrm{m}$ closedpath cell; the $y$ axis shows the corresponding relative deviation between the $1.4 \mu \mathrm{m}$ closed-path cell (in black; the $1.4 \mu \mathrm{m}$ open-path cell in purple) and the $2.6 \mu \mathrm{m}$ closed-path cell. The $\pm 10 \%$ range of the $y$ axis is chosen to show HAI's independent in-flight performance in the perspective of the results of the cited laboratory comparison AquaVIT. As explained above, there is a small offset between both instrument channels. This is not surprising as all HAI channels are evaluated completely independent in the described calibrationfree approach. The deviations between the 1.4 and $2.6 \mu \mathrm{m}$ closed-path cells of about $2 \%$ have consistently been seen in other measurements too, but they are within the metrological uncertainty of the evaluation. This systematic deviation is most likely caused by an inaccurate line strength parameter in the HITRAN (Rothman et al., 2009) database used for this evaluation. The very tiny concentration dependency $(0.18 \%$ per $1000 \mathrm{ppmv})$ of the relative deviation between the 1.4 and the $2.6 \mu \mathrm{m}$ closed-path cell reflects the larger com- plexity of evaluating the $2.6 \mu \mathrm{m}$ spectra at very high ODs e.g., approximately OD $=16$ at 8000 ppmv.

Note that an evaluation of the $2.6 \mu \mathrm{m}$ closed-path cell at 8000 ppmv is from a spectroscopic point of view similar to the evaluation of a hypothetical $160000 \mathrm{ppmv}$ concentration in the $1.4 \mu \mathrm{m}$ closed-path cell. Comparing this $160000 \mathrm{ppmv}$ with HAI's (1.4 $\mu$ m closed-path cell) calculated offset uncertainty of 3 ppmv (laboratory validations show real fluctuation of just around $0.6 \mathrm{ppmv}$ ) demonstrates the impressive linearity which can be achieved with our dTDLAS systems, like HAI, over a range of 5 to 6 orders of magnitude.

These first detailed close-ups in HAI's multi-phase measurements show the potential to investigate many interesting questions in following campaigns. To really investigate and fully understand all effects, HAI needs more data in cirrus, mixed-phase, and other clouds in a multi-phase configuration as well as a validation campaign in which closed- and open-path cells measure the pure gas-phase via a backwardfacing inlet. The latter is necessary to distinguish between sampling effects and optical or spectral effects in and outside of clouds. This knowledge, especially in combination with the mentioned CFD model, will then allow the reevaluation of HAI's raw data, which are always saved during flights, and extent statements even for this short cirrus transect.

\subsection{Performance summary}

Table 1 shows an overview of HAI's current performance features. The $2.6 \mu \mathrm{m}$ open-path channel is not mentioned due to low light transmission in the $2.6 \mu \mathrm{m}$ fiber. This problem is likely to be related to the novel ZBLAN fiber used here which prevented the $2.6 \mu \mathrm{m}$ open-path channel from excelling the $1.4 \mu \mathrm{m}$ open-path performance during the first flight campaign. It is expected for future campaigns that the optical transmission and thus the $2.6 \mu \mathrm{m}$ open-path channel performance can be improved significantly.

\section{Conclusion and outlook}

The novel Hygrometer for Atmospheric Investigation realizes a simultaneous gas-phase and total water measurement in a unique concept. Based on calibration-free direct tuneable diode laser absorption spectroscopy, HAI provides a variety of unique features as summarized in Table 1, such as accurate ( $<4 \%)$, precise $(0.065 \mathrm{ppmv}$ at $4.8 \mathrm{~Hz}$, channel depended), and very fast (down to $1.3 \mathrm{~ms}$ ) measurements with meteorologically defined uncertainties ( $4.3 \%$, channel dependent). HAI contains four measurement channels, grouped into two completely independent dual-channel spectrometers, one at 1.4 and one at $2.6 \mu \mathrm{m}$, to cover the entire $\mathrm{H}_{2} \mathrm{O}$ concentration range of the aircraft accessible atmosphere. Each spectrometer feeds light in a wavelength-individual extractive, closedpath cell with an optical absorption path length of $1.5 \mathrm{~m}$ for total water measurements. Additionally, both spectrom- 
Table 1. Performance overview of HAI: ${ }^{1}$ lower limit is defined by offset uncertainty and the upper limit by instrument temperature or spectroscopic effects; ${ }^{2}$ calculated uncertainty based on calibration-free evaluation model; ${ }^{3}$ calculated based on the accuracy level of the independent parasitic absorption minimization and determination (Buchholz and Ebert, 2014b); ${ }^{4}$ general statements for typical airborne application; ${ }^{4,5,6,7,8}$ statements based on several metrological method validations which are not part of this paper; ${ }^{9}$ precision derived from single absorption signal as described in paper; ${ }^{10}$ precision derived from Allan variance approach; ${ }^{11}$ depending on broadening of the absorption line, the maximum time resolution variates between 1 and $2 \mathrm{~ms} ;{ }^{12}$ HAI reports 120 independent measurements per second; 13 the effective time resolution is limited for the closed-path cell by the gas flow rate (exchange rate) and for the open-path cell by an minimum average number of two raw spectra to save SSD space; ${ }^{14}$ the Allan variance is not a feasible approach for retrieving reliable inflight statements; ${ }^{15}$ these open-path figures are inferred from closed-path measurements, and a direct metrological validation is not viable; 16 figures are based on a variety of studies which will be published in individual, coherent publications.

\begin{tabular}{|c|c|c|c|}
\hline & $1.4 \mu \mathrm{m} \mathrm{CP}$ & $2.6 \mu \mathrm{m} \mathrm{CP}$ & $1.4 \mu \mathrm{m} \mathrm{OP}$ \\
\hline Evaluation method & Calibration-free dTDLAS & Calibration-free dTDLAS & Calibration-free dTDLAS \\
\hline Mirror configuration & Fiber-coupled WHITE cell & Fiber-coupled WHITE cell & Fiber-coupled WHITE cell \\
\hline Optical path length & $1.5 \mathrm{~m}$ & $1.5 \mathrm{~m}$ & $4.2 \mathrm{~m}$ \\
\hline $\mathrm{H}_{2} \mathrm{O}$ concentration range ${ }^{1}$ & 3-40000 ppmv & $0.4-10000 \mathrm{ppmv}$ & $1-50000 \mathrm{ppmv}$ \\
\hline Linear uncertainty $^{2}$ & $4.3 \%$ & $5.9 \%$ & $5 \%$ \\
\hline Offset uncertainty ${ }^{3}$ & \pm 3 ppmv & $\pm 0.4 \mathrm{ppmv}$ & $\pm 1 \mathrm{ppmv}$ \\
\hline Accuracy $^{4}$ & $<4 \%{ }^{16}$ & $<4 \%{ }^{16}$ & $<6 \% 15$ \\
\hline Long-term stability ${ }^{5}$ & $0.35 \% 16$ & $0.35 \% 16$ & $0.35 \% 15$ \\
\hline Reproducibility $^{6}$ & $0.1 \% 16$ & $0.1 \%{ }^{16}$ & $2 \% 15$ \\
\hline Instrument temperature impact $^{7}$ & $0.026 \% / \mathrm{K}^{16}$ & $0.1 \% / \mathrm{K}^{16}$ & $0.026 \% / \mathrm{K}^{15}$ \\
\hline Instrument humidity impact $^{8}$ & $<0.001 \% / \% \mathrm{RH}^{16}$ & $<0.001 \% / \% \mathrm{RH}^{16}$ & $<0.001 \% / \% \mathrm{RH}^{15}$ \\
\hline Precision $\mathrm{A}^{9}$ at $4.8 \mathrm{~Hz} \& 200 \mathrm{ppmv}$ & $1.9 \mathrm{ppmv}$ & $0.49 \mathrm{ppmv}$ & $2.1 \mathrm{ppmv}$ \\
\hline Precision $\mathrm{A}^{9}$ normalized & $1.3 \mathrm{ppmv} \mathrm{m} \mathrm{Hz}^{-1 / 2}$ & $0.35 \mathrm{ppbv} \mathrm{m} \mathrm{Hz}^{-1 / 2}$ & $4.6 \mathrm{ppmv} \mathrm{m} \mathrm{Hz}^{-1 / 2}$ \\
\hline Precision $\mathrm{B}^{10}$ at $4.8 \mathrm{~Hz} \& 200 \mathrm{ppmv}$ & $0.22 \mathrm{ppmv}$ & $0.065 \mathrm{ppmv}$ & 14 \\
\hline Best precision $\mathrm{B}^{10}$ at $200 \mathrm{ppmv}$ & $0.18 \mathrm{ppmv}(3.9 \mathrm{~Hz})$ & $0.55 \mathrm{ppmv}(13 \mathrm{~Hz})$ & 14 \\
\hline Best precision $\mathrm{B}^{10}$ normalized & $187 \mathrm{ppbv} \mathrm{m} \mathrm{Hz}-1 / 2$ & $31 \mathrm{ppbv} \mathrm{m} \mathrm{Hz}^{-1 / 2}$ & 14 \\
\hline Maximum optical time resolution ${ }^{11}$ & $1.3 \mathrm{~ms}$ & $1.3 \mathrm{~ms}$ & $1.3 \mathrm{~ms}$ \\
\hline Maximum measurement frequency 12 & $120 \mathrm{~Hz}$ & $120 \mathrm{~Hz}$ & $120 \mathrm{~Hz}$ \\
\hline Effective time resolution ${ }^{13}$ & $0.7 \mathrm{~s}$ & $0.7 \mathrm{~s}$ & $2.6 \mathrm{~ms}$ \\
\hline Spatial averaging at $800 \mathrm{~km} \mathrm{~h}^{-1}$ & $155 \mathrm{~m}$ & $155 \mathrm{~m}$ & $0.57 \mathrm{~m}$ \\
\hline
\end{tabular}

eters couple their light in a common open-path cell (optical path of $4.8 \mathrm{~m}$ ) located outside of the aircraft fuselage, for a sampling-free and contactless determination of the gas-phase water content. These four spectroscopic channels plus three additional supplementary spectroscopic channels allow multiple self-validation strategies inside and outside of clouds and therefore solve the current lack of an integrated approach to validate open-path sensors in flight. HAI's complex control software minimizes maintenance at ground and ensures almost entirely autonomous operation. In addition, instrument health is permanently supervised by permanent storage of more than 120 housekeeping data. This enables a novel, holistic quality management and a sophisticated signal cross check, which guarantees a high trust level of the final $\mathrm{H}_{2} \mathrm{O}$ values.

HAI was operated for the first time during the TACTS/ESMVal flight campaign for more than 120 operation hours without any malfunction. The entirely independent, never-calibrated first-principle evaluation of the closedpath spectrometer channels yields in-flight deviations of only $1.9 \%$ over a large concentration ( 75 to 2000 ppmv) and pres- sure range (175 to $450 \mathrm{hPa})$. The deviation between the openpath and the closed-path measurements in the same flight segment was on average just $2 \%$, with a short-term deviation between +3 and $-5 \%$. Despite measuring with a single evaluation concept, over a very broad range of conditions (i.e., temperatures $\left(-70\right.$ to $\left.30^{\circ} \mathrm{C}\right)$, gas speeds $\left(\mathrm{cm} \mathrm{s}^{-1} \mathrm{vs}\right.$. $100 \mathrm{~m} \mathrm{~s}^{-1}$ ), and optical disturbances (no background light vs. sunlight; clean mirrors vs. dirty scratched mirrors outside), HAI provided a high trust level of the data over extensive science missions. Laboratory evaluations demonstrated the lowest achievable precision of $0.18 \mathrm{ppmv}$ (at $3.8 \mathrm{~Hz}$ ) for the $1.4 \mu \mathrm{m}$ closed-path cell and $0.055 \mathrm{ppmv}$ (at $13 \mathrm{~Hz}$ ) for the $2.6 \mu \mathrm{m}$ closed-path cell.

In conclusion, HAI proved during its first deployment a novel, highly complex, and demanding set of capabilities. This will enable in the future a much more accurate and stringent evaluation of atmospheric multi-phase water vapor data inside and outside of clouds and foster in further HALO missions the investigation of new scientific questions in the atmospheric water cycle. HAI can serve in the future as a ma- 
jor, powerful tool for cutting-edge atmospheric water vapor measurements.

\section{Data availability}

HAI's data are available on the HALO database https:// halo-db.pa.op.dlr.de/.

Acknowledgements. Parts of this work were funded by the Deutsche Forschungsgemeinschaft (DFG) via FKZ EBE 235/3 and SCHI 872/2. Numerous metrological questions were partially co-funded via the EMRP/EMPIR projects METEOMET-1 and METEOMET-2. The EMRP/EMPIR is jointly funded by the EMRP/EMPIR participating countries within EURAMET and the European Union. The authors wish to thank M. Riese (Forschungszentrum Jülich) for the strong continued support of the project, Mark Zondlo (University Princeton) for sharing his significant knowledge about atmospheric water vapor measurements, A. Engel and H. Bönisch (Goethe Universität Frankfurt) for their coordination of the TACTS campaign, H. Schlager for organizing the ESMVal campaign, and A. Giez, M. Zöger, V. Dreiling, K. Witte, and A. Minikin, representatives of the Deutsche Luft und Raumfahrtzentrum Oberpfaffenhofen, for providing the HALO avionic data.

Edited by: D. Toohey

Reviewed by: three anonymous referees

\section{References}

Allan, D. W.: Statistics of atomic frequency standards, Proceedings of the IEEE, 54, 221-230, doi:10.1109/PROC.1966.4634, 1966.

Brewer, P. J., Milton, M. J., Harris, P. M., Bell, S. A., Stevens, M., Scace, G., Abe, H., and Mackrodt, P.: Euramet 1002: International comparability in measurements of trace water vapour, in National Physical Laboratory Report AS 59, 2011.

Buchholz, B.: Entwicklung, Primärvalidierung und Feldeinsatz neuartiger, kalibrierungsfreier Laser-Hygrometer für Forschungsflugzeuge, Dissertation TU-Darmstadt, available at: http://tuprints.ulb.tu-darmstadt.de/4020/ (last access: 18 December 2016), 2014.

Buchholz, B. and Ebert, V.: Compact, compression-free, displaceable, and resealable vacuum feedthrough with built-in strain relief for sensitive components such as optical fibers, Rev. Sci. Instrum., 85, 055109, doi:10.1063/1.4872076, 2014a.

Buchholz, B. and Ebert, V.: Offsets in fiber-coupled diode laser hygrometers caused by parasitic absorption effects and their prevention, Meas. Sci. and Technol., 25, 075501, doi:10.1088/09570233/25/7/075501, 2014b.

Buchholz, B., Böse, N., Wagner, S., and Ebert, V.: Entwicklung eines rückführbaren, selbstkalibrierenden, absoluten TDLASHygrometers in kompakter 19" Bauweise, in AMA-Science, GMA/ITG-Fachtagung Sensoren und Messsysteme 2012, 16, 315-323, 2012.

Buchholz, B., Afchine, A., Klein, A., Barthel, J., Klostermann, T., Kallweit, S., Krämer, M., Schiller, C., and Ebert, V.:
Eine neue, fasergekoppelte offene White-Zelle für die "openpath"-Gasanalyse auf Forschungsflugzeugen, in DGAO Proceedings, available at: http://www.dgao-proceedings.de/download/ 114/114_b35.pdf (last access: 18 December 2016), 2013a.

Buchholz, B., Kühnreich, B., Smit, H. G. J., and Ebert, V.: Validation of an extractive, airborne, compact TDL spectrometer for atmospheric humidity sensing by blind intercomparison, Appl. Phys. B, 110, 249-262, doi:10.1007/s00340-012-5143-1, 2013b.

Buchholz, B., Böse, N., and Ebert, V.: Absolute validation of a diode laser hygrometer via intercomparison with the German national primary water vapor standard, Appl. Phys. B, 116, 883899, doi:10.1007/s00340-014-5775-4, 2014a.

Buchholz, B., Afchine, A., and Ebert, V.: Rapid, optical measurement of the atmospheric pressure on a fast research aircraft using open-path TDLAS, Atmos. Meas. Tech., 7, 3653-3666, doi:10.5194/amt-7-3653-2014, 2014b.

Buck, A.: The Lyman-alpha absorption hygrometer, in Moisture and Humidity Symposium Washington, DC, Research Triangle Park, NC, 411-436, 1985.

Busen, R. and Buck, A. L.: A High-Performance Hygrometer for Aircraft Use: Description, Installation, and Flight Data, J. Atmos. Ocean. Technol., 12, 73-84, 1995.

Cerni, T. A.: An Infrared Hygrometer for Atmospheric Research and Routine Monitoring, J. Atmos. Ocean. Technol., 11, 445462, 1994.

Desjardins, R., MacPherson, J., Schuepp, P., and Karanja, F.: An evaluation of aircraft flux measurements of $\mathrm{CO}_{2}$, water vapor and sensible heat, Bound.-Lay. Meteorol., 47, 55-69, doi:10.1007/BF00122322, 1989.

Diskin, G. S., Podolske, J. R., Sachse, G. W., and Slate, T. A.: Openpath airborne tunable diode laser hygrometer, in Proc. SPIE 4817, Diode Lasers and Applications in Atmospheric Sensing, 4817, 196-204, 2002.

Duffin, K., McGettrick, A. J., Johnstone, W., Stewart, G., and Moodie, D. G.: Tunable diode-laser spectroscopy with wavelength modulation: A calibration-free approach to the recovery of absolute gas absorption line shapes, J. Lightwave Technol., 25, 3114-3125, doi:10.1109/JLT.2007.904937, 2007.

Durry, G., Amarouche, N., Joly, L., and Liu, X.: Laser diode spectroscopy of $\mathrm{H}_{2} \mathrm{O}$ at $2.63 \mu \mathrm{m}$ for atmospheric applications, Appl Phys. B, 90, 573-580, doi:10.1007/s00340-007-2884-3, 2008.

Ebert, V.: In situ absorption spectrometers using near-IR diode lasers and rugged multi-path-optics for environmental field measurements, Laser Applilcations to Chemical, Security and Environmental Analysis, Technical Digest (Optical Society of America), paper WB1, doi:10.1364/LACSEA.2006.WB1, 2006.

Ebert, V. and Wolfrum, J.: Absorption spectroscopy, in OPTICAL MEASUREMENTS-Techniques and Applications, edited by: Mayinger, F., 273-312, Springer, 1994.

Ebert, V. and Wolfrum, J.: Absorption spectroscopy, in Optical Measurements - Techniques and Applications (Heat and Mass Transfer), edited by: Mayinger, F. and Feldmann, O., Springer Heidelberg, München, 273-312, 2000.

Ebert, V., Fernholz, T., and Pitz, H.: In-situ monitoring of water vapor and gas temperature in a coal fired power-plant using near-infrared diode lasers, in Laser Applications to Chemical and Environmental Analysis, 26, 77-79, OSA Technical Digest (Optical Society of America, Washington DC), available at: 
http://www.opticsinfobase.org/abstract.cfm?id=142068 (last access: 25 November 2013), 2000a.

Ebert, V., Fernholz, T., and Pitz, H.: In-situ monitoring of water vapour and gas temperature in a coal fired power-plant using near-infrared diode lasers, in Laser Applications to Chemical and Environmental Analysis, 4-6, Optical Society of America, available at: http://www.opticsinfobase.org/abstract.cfm?id=142068 (last access: 15 February 2012), 2000b.

Ebert, V., Teichert, H., Giesemann, C., Saathoff, H., and Schurath, U.: Fibre-Coupled In-situ Laser Absorption Spectrometer for the Selective Detection of Water Vapour Traces down to the ppbLevel, in tm - Technisches Messen, Düsseldorf, 72, 23-30, 2004.

Engel, A., Boenisch, H., and TACTS-Team: An overview on the TACTS mission using the new German research aircraft HALO in summer 2012, EGU General Assembly, 15, available at: http: //adsabs.harvard.edu/abs/2013EGUGA15.9191E, last access: 1 August 2013.

Fahey, D. and Gao, R.: Summary of the AquaVIT Water Vapor Intercomparison: Static Experiments, source: https: //aquavit.icg.kfa-juelich.de/WhitePaper/AquaVITWhitePaper_ Final_23Oct2009_6MB.pdf (last access: May 2014), 2009.

Fahey, D. W., Gao, R.-S., Möhler, O., Saathoff, H., Schiller, C., Ebert, V., Krämer, M., Peter, T., Amarouche, N., Avallone, L. M., Bauer, R., Bozóki, Z., Christensen, L. E., Davis, S. M., Durry, G., Dyroff, C., Herman, R. L., Hunsmann, S., Khaykin, S. M., Mackrodt, P., Meyer, J., Smith, J. B., Spelten, N., Troy, R. F., Vömel, H., Wagner, S., and Wienhold, F. G.: The AquaVIT-1 intercomparison of atmospheric water vapor measurement techniques, Atmos. Meas. Tech., 7, 3177-3213, doi:10.5194/amt-7-3177-2014, 2014.

Farooq, A., Jeffries, J., and Hanson, R.: In situ combustion measurements of $\mathrm{H}_{2} \mathrm{O}$ and temperature near $2.5 \mu \mathrm{m}$ using tunable diode laser absorption, Meas. Sci. Technol., 19, 075604, doi:10.1088/0957-0233/19/7/075604, 2008.

Friehe, C., Grossman, R., and Pann, Y.: Calibration of an airborne Lyman-alpha hygrometer and measurement of water vapor flux using a thermoelectric hygrometer, J. Atmos. Ocean. Technol., 3, 299-304, 1986.

Giez, A.: Effective test and calibration of a trailing cone system on the atmospheric research aircraft HALO, Proceedings of the 56th Annual Symposium of the Society of Experimental Test Pilots, Sep. 2012, 2012.

Goldenstein, C. S., Strand, C. L., Schultz, I. A., Sun, K., Jeffries, J. B., and Hanson, R. K.: Fitting of calibration-free scannedwavelength-modulation spectroscopy spectra for determination of gas properties and absorption lineshapes, Appl. Opt., 53, 35667, doi:10.1364/AO.53.000356, 2014.

Gurlit, W., Zimmermann, R., Giesemann, C., Fernholz, T., Ebert, V., Wolfrum, J., Platt, U. U., and Burrows, J. P.: Lightweight diode laser spectrometer "CHILD" for balloon- borne measurements of water vapor and methane, Appl. Opt., 44, 91-102, doi:10.1364/AO.44.000091, 2005.

HALO: High Altitude and LOng range research aircraft, http:// www.halo.dlr.de/, last accessed: October 2016.

Hansford, G. M., Freshwater, R. A., Eden, L., Turnbull, K. F. V., Hadaway, D. E., Ostanin, V. P., and Jones, R. L.: Lightweight dew-/frost-point hygrometer based on a surfaceacoustic-wave sensor for balloon-borne atmospheric water va- por profile sounding, Rev. Sci. Instrum., 77, 014502-014502, doi:10.1063/1.2140275, 2006.

Held, I. and Soden, B.: Water vapor feedback and global warming, Annu. Rev. Energ. Environ., 25, 441-475, doi:10.1146/annurev.energy.25.1.441, 2000.

Helten, M., Smit, H. G. J., Sträter, W., Kley, D., Nedelec, P., Zöger, M., and Busen, R.: Calibration and performance of automatic compact instrumentation for the measurement of relative humidity from passenger aircraft, J. Geophys. Res.-Atmos., 103, 25643-25652, doi:10.1029/98JD00536, 1998.

Hoff, A.: WVSS-II Assessment at the DWD Deutscher Wetterdienst/German Meteorological Service Climate Chamber of the Meteorological Observatory Lindenberg, Deutscher Wetterdienst, 2009.

Houghton, J.: Global Warming: The Complete Briefing 4th Edition by John Houghton, ISBN-13: 978-0521709163, ISBN-10: 0521709164, 2009.

Hovde, D., Hodges, J., Scace, G., and Silver, J.: Wavelengthmodulation laser hygrometer for ultrasensitive detection of water vapor in semiconductor gases, Appl. Opt., 40, 829-839, doi:10.1364/AO.40.000829, 2001.

Hunsmann, S., Wagner, S., Saathoff, H., Möhler, O., Schurath, U., and Ebert, V.: Messung der Temperaturabhängigkeit der Linienstärken und Druckverbreiterungskoeffizienten von $\mathrm{H}_{2} \mathrm{O}$ Absorptionslinien im 1.4 $\mu \mathrm{m}$ Band, in VDI Berichte (1959) VDI Verlag, Düsseldorf, 149-164, 2006.

Hunsmann, S., Wunderle, K., Wagner, S., Rascher, U., Schurr, U., and Ebert, V.: Absolute, high resolution water transpiration rate measurements on single plant leaves via tunable diode laser absorption spectroscopy (TDLAS) at $1.37 \mu \mathrm{m}$, Appl. Phys. B, 92, 393-401, doi:10.1007/s00340-008-3095-2, 2008.

JCGM 2008: 2008 International vocabulary of metrology - Basic and general concepts and associated terms (VIM) Vocabulaire international de métrologie - Concepts fondamentaux et généraux et termes associés (VIM), International Organization for Standardization, 3(Vim), 104, doi:10.1016/0263-2241(85)90006-5, 2008.

Joint Committee for Guides in Metrology (JCGM): Evaluation of measurement data - Guide to the expression of uncertainty in measurement JCGM 100:2008, BIPM: Bureau International des Poids et Mesures, www.bipm.org(last access: 18 December 2016), 2008.

Joint Committee for Guides in Metrology (JCGM): Evaluation of measurement data - An introduction to the "Guide to the expression of uncertainty in measurement" and related documents, BIPM: Bureau International des Poids et Mesures, www.bipm. org (last access: 18 December 2016), 2009.

Kaufmann, S., Voigt, C., Jurkat, T., Thornberry, T., Fahey, D. W., Gao, R.-S., Schlage, R., Schäuble, D., and Zöger, M.: The airborne mass spectrometer AIMS - Part 1: AIMS-H2O for UTLS water vapor measurements, Atmos. Meas. Tech., 9, 939-953, doi:10.5194/amt-9-939-2016, 2016.

Kiehl, J. T. and Trenberth, K. E.: Earth's Annual Global Mean Energy Budget, B. Am. Meteorol. Soc., 78, 197-208, 1997.

Kiemle, C., Schäfler, A., and Voigt, C.: Detection and analysis of water vapor transport, in Atmospheric Physics, Springer Berlin Heidelberg, 169-184, 2012. 
Kley, D. and Stone, E.: Measurement of water vapor in the stratosphere by photodissociation with Ly $\alpha(1216 \AA)$ light, Rev. Sci. Instrum., 49, 691, doi:10.1063/1.1135596, 1978.

Klostermann, T.: Entwicklung und Erprobung des Hygrometer for Atmospheric Investigations, Schriften des Forschungszentrums Jülich?: Energie \& Umwelt/Energy \& Environment, 113 pp., 2011.

Krämer, M. and Afchine, A.: Sampling characteristics of inlets operated at low U/U0 ratios: new insights from computational fluid dynamics (CFX) modeling, J. Aerosol Sci., 35, 683-694, doi:10.1016/j.jaerosci.2003.11.011, 2004.

Krämer, M., Schiller, C., Afchine, A., Bauer, R., Gensch, I., Mangold, A., Schlicht, S., Spelten, N., Sitnikov, N., Borrmann, S., de Reus, M., and Spichtinger, P.: Ice supersaturations and cirrus cloud crystal numbers, Atmos. Chem. Phys., 9, 3505-3522, doi:10.5194/acp-9-3505-2009, 2009.

Krautstrunk, M. and Giez, A.: The Transition From FALCON to HALO Era Airborne Atmospheric Research, in Atmospheric Physics, edited by: Schumann, U., 609-624, 2012.

Kühnreich, B., Klein, A., Höh, M., Buchholz, B., and Ebert, V.: Kompakte, direkt fasergekoppelte Multipass-Zellen für spektroskopische Anwendungen im NIR-und MIR-Bereich, in: DGAO Proceedings, available at: http://www.dgao-proceedings. de/download/114/114_p35.pdf, last access: 11 October 2013.

Lackner, M.: Tunable diode laser absorption spectroscopy (TDLAS) in the process industries - a review, Rev. Chem. Eng., 23, 65-147, doi:10.1515/REVCE.2007.23.2.65, 2011.

Lockwood, J. G.: Clouds and the atmospheric radiation balance, Prog. Phys. Geogr., 14, 89-96, doi:10.1177/030913339001400106, 1990.

Lu, E. and Takle, E. S.: Spatial variabilities and their relationships of the trends of temperature, water vapor, and precipitation in the North American Regional Reanalysis, J. Geophys. Res., 115, D06110, doi:10.1029/2009JD013192, 2010.

Lübken, F.-J., Dingler, F., Lucke, H. von, Anders, J., Riedel, W. J., and Wolf, H.: MASERATI: a rocketborne tunable diode laser absorption spectrometer, Appl. Opt., 38, 5338-5349, doi:10.1364/AO.38.005338, 1999.

Ludlam, F.: Clouds and storms: The behavior and effect of water in the atmosphere available at: http://agris.fao.org/agris-search/ search.do?recordID=US8025686 (last access: 24 May 2014), 1980.

Mackrodt, P.: A New Attempt on a Coulometric Trace Humidity Generator, International J. Thermophys., 33, 1520-1535, doi:10.1007/s10765-012-1348-0, 2012.

Mangold, A. and Wodca Team: Intercomparison of water vapour detectors under field and defined conditions, EGS-AGUEUG Joint Assembly, available at: http://adsabs.harvard.edu/abs/ 2003EAEJA9330M (last access: 1 March 2014), 2003.

May, R. D.: Open-path, near-infrared tunable diode laser spectrometer for atmospheric measurements of $\mathrm{H}_{2} \mathrm{O}$, J. Geophys. Res., 103, 19161-19172, doi:10.1029/98JD01678, 1998.

Maycock, A. C., Shine, K. P., and Joshi, M. M.: The temperature response to stratospheric water vapour changes, Q. J. Roy. Meteorol. Soc., 137, 1070-1082, doi:10.1002/qj.822, 2011.

McCarthy, M. P., Thorne, P. W., and Titchner, H. a.: An Analysis of Tropospheric Humidity Trends from Radiosondes, J. Climate, 22, 5820-5838, doi:10.1175/2009JCLI2879.1, 2009.
McManus, J., Kebabian, P., and Zahniser, M.: Astigmatic mirror multipass absorption cells for long-path-length spectroscopy, Appl. Opt., 34, 3336-3348, doi:10.1364/AO.34.003336, 1995.

Meyer, J., Rolf, C., Schiller, C., Rohs, S., Spelten, N., Afchine, A., Zöger, M., Sitnikov, N., Thornberry, T. D., Rollins, A. W., Bozóki, Z., Tátrai, D., Ebert, V., Kühnreich, B., Mackrodt, P., Möhler, O., Saathoff, H., Rosenlof, K. H., and Krämer, M.: Two decades of water vapor measurements with the FISH fluorescence hygrometer: a review, Atmos. Chem. Phys., 15, 85218538, doi:10.5194/acp-15-8521-2015, 2015.

Mihalcea, R., Baer, D., and Hanson, R.: Diode laser sensor for measurements of $\mathrm{CO}, \mathrm{CO}_{2}$, and $\mathrm{CH}_{4}$ in combustion flows, Appl. Opt., 36, 8745-8752, doi:10.1364/AO.36.008745, 1997.

Miloshevich, L. M., Vömel, H., Whiteman, D. N., Lesht, B. M., Schmidlin, F. J., and Russo, F.: Absolute accuracy of water vapor measurements from six operational radiosonde types launched during AWEX-G and implications for AIRS validation, J. Geophys. Res.-Atmos., 111, D09S10, doi:10.1029/2005JD006083, 2006.

Möller, D., Feichter, J., and Herrmann, H.: Von Wolken, Nebel und Niederschlag, in Chemie über den Wolken: und darunter, edited by: Zellner, R., WILEY-VCH Verlag GmbH \& Co. KGaA, Weinheim, 236-240, 2011.

Muecke, R. J., Scheumann, B., Slemr, F., and Werle, P. W.: Calibration procedures for tunable diode laser spectrometers, Proc. SPIE 2112, Tunable Diode Laser Spectroscopy, Lidar, and DIAL Techniques for Environmental and Industrial Measurement, 2112, 8798, doi:10.1117/12.177289, 1994.

Ohtaki, E. and Matsui, T.: Infrared device for simultaneous measurement of fluctuations of atmospheric carbon dioxide and water vapor, Bound.-Lay. Meteorol., 24, 109-119, doi:10.1007/BF00121803, 1982.

Oltmans, S. and Hofmann, D.: Increase in lower-stratospheric water vapour at a mid-latitude Northern Hemisphere site from 1981 to 1994, Nature, 374, 146-149, doi:10.1038/374146a0, 1995.

Peter, T., Marcolli, C., Spichtinger, P., Corti, T., Baker, M. B., and Koop, T.: When dry air is too humid, Science, 314, 1399-1402, doi:10.1126/science.1135199, 2006.

Petersen, R., Cronce, L., Feltz, W., Olson, E., and Helms, D.: WVSS-II moisture observations: A tool for validating and monitoring satellite moisture data, EUMETSAT Meteorological Satellite Conference, 22, 67-77 available at: http://amdar.noaa.gov/ docs/Petersen_presentation.pdf (last access: 18 December 2016), 2010.

Podolske, J. and Loewenstein, M.: Airborne tunable diode laser spectrometer for trace-gas measurement in the lower stratosphere, Appl. Opt., 32, 5324-5333, doi:10.1364/AO.32.005324, 1993.

Podolske, J., Sachse, G., and Diskin, G.: Calibration and data retrieval algorithms for the NASA Langley/Ames Diode Laser Hygrometer for the NASA Transport and Chemical Evolution Over the Pacific (TRACE-P) mission, J. Geophys. Res., 108, 8792, doi:10.1029/2002JD003156, 2003.

Ramanathan, V., Cess, R. D., Harrison, E. F., Minnis, P., Barkstrom, B. R., Ahmad, E., and Hartmann, D.: Cloudradiative forcing and climate: results from the Earth radiation budget experiment, Science (New York, NY), 243, 57-63, doi:10.1126/science.243.4887.57, 1989. 
Ravishankara, A. R.: Water Vapor in the Lower Stratosphere, Science, 337, 809-810, doi:10.1126/science.1227004, 2012.

Rieker, G., Jeffries, J., and Hanson, R.: Calibration-free wavelength-modulation spectroscopy for measurements of gas temperature and concentration in harsh environments, Appl. Opt., 48, 5546-5560, doi:10.1364/AO.48.005546, 2009.

Rollins, A., Thornberry, T., Gao, R. S., Smith, J. B., Sayres, D. S., Sargent, M. R., Schiller, C., Krämer, M., Spelten, N., Hurst, D. F., Jordan, A. F., Hall, E. G., Vömel, H., Diskin, G. S., Podolske, J. R., Christensen, L. E., Rosenlof, K. H., Jensen, E. J., and Fahey, D. W.: Evaluation of UT/LS hygrometer accuracy by intercomparison during the NASA MACPEX mission, J. Geophys. Res.-Atmos., 119, doi:10.1002/2013JD020817, 2014.

Rosenlof, K. H., Oltmans, S. J., Kley, D., III, J. M. R., Chiou, E.-W., Chu, W. P., Johnson, D. G., Kelly, K. K., Michelsen, H. A., Nedoluha, G. E., Remsberg, E. E., Toon, G. C., and McCormick, M. P.: Stratospheric water vapor increases over the past half-century, Geophys. Res. Lett., 28, 1195-1198, doi:10.1029/2000GL012502, 2001.

Ross, R. and Elliott, W.: Tropospheric water vapor climatology and trends over North America: 1973-93, J. Climate, 9, 3561-3574, 1996.

Rothman, L. S., Gordon, I. E., Barbe, A., Benner, D. C., Bernath, P. F., Birk, M., Boudon, V., Brown, L. R., Campargue, A., and Champion, J.-P.: The HITRAN 2008 molecular spectroscopic database, J. Quant. Spectrosc. Ra., 110, 533-572, doi:10.1016/j.jqsrt.2009.02.013, 2009.

Roths, J. and Busen, R.: Development of a laser in situ airborne hygrometer (LISAH) (feasibility study), Infrared Phys. Techn., 37, 33-38, doi:10.1016/1350-4495(95)00103-4, 1996.

Salasmaa, E. and Kostamo, P.: HUMICAP ${ }^{\circledR}$ thin film hymidity sensor, in Advanced Agricultural Instrumentation Series E: Applied Sciences, edited by: Gensler, W. G., Kluwer, 135-147, 1986.

Sargent, M. R., Sayres, D. S., Smith, J. B., Witinski, M., Allen, N. T., Demusz, J. N., Rivero, M., Tuozzolo, C., and Anderson, J. G.: A new direct absorption tunable diode laser spectrometer for high precision measurement of water vapor in the upper troposphere and lower stratosphere, Rev. Sci. Instrum., 84, 074102, doi:10.1063/1.4815828, 2013.

Schäfler, A., Döörnbrack, A., Kiemle, C., Rahm, S., Wirth, M., Schäfler, A., and Dörnbrack, A.: Tropospheric Water Vapor Transport as Determined from Airborne Lidar Measurements, J. Atmos. Ocean. Technol., 27, 2017-2030, doi:10.1175/2010JTECHA1418.1, 2010.

Scherer, M., Vömel, H., Fueglistaler, S., Oltmans, S. J., and Staehelin, J.: Trends and variability of midlatitude stratospheric water vapour deduced from the re-evaluated Boulder balloon series and HALOE, Atmos. Chem. Phys., 8, 1391-1402, doi:10.5194/acp8-1391-2008, 2008.

Schiff, H. I., Mackay, G. I., and Bechara, J.: The use of tunable diode laser absorption spectroscopy for atmospheric measurements, Res. Chem. Intermediat., 20, 525-556, doi:10.1163/156856794X00441, 1994.

Schlager, H.: ESMVal (Earth System Model Validation), available at: http://www.pa.op.dlr.de/ESMVal, last accessed: May 2014.

Schlosser, H. E., Fernholz, T., Teichert, H., and Ebert, V.: In situ detection of potassium atoms in high-temperature coal-combustion systems using near-infrared-diode lasers, Spectrochim. Acta A, 58, 2347-2359, doi:10.1016/S1386-1425(02)00049-5, 2002.
Schneider, S.: Cloudiness as a global climatic feedback mechanism: The effects on the radiation balance and surface temperature of variations in cloudiness, J. Atmos. Sci., 29, 1413-1422, 1972.

Schulz, C., Dreizler, A., Ebert, V., and Wolfrum, J.: Combustion Diagnostics, in Handbook of Experimental Fluid Mechanics, edited by: Tropea, C., Yarin, A. L., and Foss, J. F., Springer Berlin Heidelberg, Heidelberg, 1241-1316, 2007.

Seidel, A., Wagner, S., and Ebert, V.: TDLAS-based open-path laser hygrometer using simple reflective foils as scattering targets, Appl. Phys. B, 109, 497-504, doi:10.1007/s00340-012-5228-x, 2012.

Sherwood, S., Bony, S., and Dufresne, J.: Spread in model climate sensitivity traced to atmospheric convective mixing, Nature, 505, 37-42, doi:10.1038/nature12829, 2014.

Silver, J. and Hovde, D.: Near-infrared diode laser airborne hygrometer, Rev. Sci. Instrum., 65, 5, 1691-1694, 1994a.

Silver, J. A. and Hovde, D. C.: Near-infrared diode laser airborne hygrometer, Rev. Sci. Instrum., 65, 1691-1694, doi:10.1063/1.1144861, 1994b.

Silver, J. and Zondlo, M.: High-precision $\mathrm{CO}_{2}$ sensor for meteorological balloons, in SPIE Proceedings 6378, Chemical and Biological Sensors for Industrial and Environmental Monitoring II, 63780J, 2006.

Silver, J. A.: Frequency-modulation spectroscopy for trace species detection: theory and comparison among experimental methods: errata, Appl. Opt., 31, 4927-4927, doi:10.1364/AO.31.004927, 1992.

Smit, H. G. J., Strater, W., Helten, M., and Kley, D.: Environmental simulation facility to calibrate airborne ozone and humidity sensors, in Forschungszentrum Jülich Berichte 3796, Forschungszentrum Julich, Zentralbibliothek., available at: http: //www.opengrey.eu/item/display/10068/253740 (last access: 25 November 2013), 2000.

Smit, H. G. J., Rolf, C., Kraemer, M., Petzold, A., Spelten, N., Neis, P., Maser, R., Buchholz, B., Ebert, V., and Tatrai, D.: Development and Evaluation of Novel and Compact Hygrometer for Airborne Research (DENCHAR): In-Flight Performance During AIRTOSS-I/II Research Aircaft Campaigns, Geophysical Research Abstracts, 16 (EGU2014-9420), 2014.

Smorgon, D., Boese, N., Ebert, V., and Team, A.: Airborne hygrometer calibration inter-comparison against a metrological water vapour standard, Geophysical Research Abstracts, 16 (EGU2014-5929), 2014.

Solomon, S., Rosenlof, K. H., Portmann, R. W., Daniel, J. S., Davis, S. M., Sanford, T. J., and Plattner, G.-K.: Contributions of stratospheric water vapor to decadal changes in the rate of global warming, Science, New York, NY, 327, 1219-23, doi:10.1126/science.1182488, 2010.

Spichtinger, P., Gierens, K., Smit, H. G. J., Ovarlez, J., and Gayet, J.-F.: On the distribution of relative humidity in cirrus clouds, Atmos. Chem. Phys., 4, 639-647, doi:10.5194/acp-4-639-2004, 2004.

Sun, K., Sur, R., Chao, X., Jeffries, J. B., Hanson, R. K., Pummill, R. J., and Whitty, K. J.: TDL absorption sensors for gas temperature and concentrations in a high-pressure entrained-flow coal gasifier, Proceedings of the Combustion Institute, 34, 35933601, doi:10.1016/j.proci.2012.05.018, 2013.

Szakáll, M., Bozóki, Z., Mohácsi, Á., Varga, T., Szabó, G., and Varga, A.: Diode laser based photoacoustic water vapor detection 
system for atmospheric research, Appl. Spectrosc., 58, 792-798, doi:10.1366/0003702041389373, 2004.

Teichert, H., Fernholz, T., and Ebert, V.: Simultaneous in-situ measurement of $\mathrm{CO}, \mathrm{H}_{2} \mathrm{O}$, and gas temperatures in a full-sized coalfired power plant by near-infrared diode lasers, Appl. Opt., 42, 2043-2051, doi:10.1364/AO.42.002043, 2003.

Thornberry, T. D., Rollins, A. W., Gao, R. S., Watts, L. A., Ciciora, S. J., McLaughlin, R. J., Voigt, C., Hall, B., and Fahey, D. W.: Measurement of low-ppm mixing ratios of water vapor in the upper troposphere and lower stratosphere using chemical ionization mass spectrometry, Atmos. Meas. Tech., 6, 1461-1475, doi:10.5194/amt-6-1461-2013, 2013.

Thornberry, T. D., Rollins, A. W., Gao, R. S., Watts, L. A., Ciciora, S. J., McLaughlin, R. J., and Fahey, D. W.: A two-channel, tunable diode laser-based hygrometer for measurement of water vapor and cirrus cloud ice water content in the upper troposphere and lower stratosphere, Atmos. Meas. Tech., 8, 211-224, doi:10.5194/amt-8-211-2015, 2015.

Trenberth, K. E., Fasullo, J., and Smith, L.: Trends and variability in column-integrated atmospheric water vapor, Clim. Dynam., 24, 741-758, doi:10.1007/s00382-005-0017-4, 2005.

UCAR/NCAR: Earth Observing Laboratory, 2005-present, NSF/NCAR GV HIAPER Aircraft, doi:10.5065/D6DR2SJP, 2016.

Vance, A. K., Woolley, A., Cotton, R., Turnbull, K., Abel, S., and Harlow, C.: Final Report on the WVSS-II Sensors fitted to the FAAM BAe 146, in Met Office, Met Office, 0-31, 2011.

Vance, A. K., Abel, S. J., Cotton, R. J., and Woolley, A. M.: Performance of WVSS-II hygrometers on the FAAM research aircraft, Atmos. Meas. Tech., 8, 1617-1625, doi:10.5194/amt-81617-2015, 2015.

Vömel, H., David, D., and Smith, K.: Accuracy of tropospheric and stratospheric water vapor measurements by the cryogenic frost point hygrometer: Instrumental details and observations, J. Geophys. Res.-Atmos., 112, 1-14, doi:10.1029/2006JD007224, 2007.

Wagner, S., Klein, M., Kathrotia, T., and Riedel, U.: Absolute, spatially resolved, in situ $\mathrm{CO}$ profiles in atmospheric laminar counter-flow diffusion flames using $2.3 \mu \mathrm{m}$ TDLAS, Appl. Phys. B, 109, 533-540, doi:10.1007/s00340-012-5242-z, 2012.

Webster, C., Flesch, G., Mansour, K., Haberle, R., and Bauman, J.: Mars laser hygrometer, Appl. Opt., 43, 4436-4445, doi:10.1364/AO.43.004436, 2004.

Weinstock, E., Hintsa, E. J., Dessler, A. E., Oliver, J. F., Hazen, N. L., Demusz, J. N., Allen, N. T., Lapson, L. B., and Anderson, J. G.: New fast response photofragment fluorescence hygrometer for use on the NASA ER-2 and the Perseus remotely piloted aircraft, Rev. Sci. Instrum., 65, 3544-3554, doi:10.1063/1.1144536, 1994.
Werle, P.: A review of recent advances in semiconductor laser based gas monitors, Spectrochim. Acta A, 54, 197-236, doi:10.1016/S1386-1425(97)00227-8, 1998.

White, J.: Very long optical paths in air, J. Opt. Soc. Am., 66, 411416, doi:10.1364/JOSA.66.000411, 1976.

Wiederhold, P. R.: Water Vapor Measurement, Methods and Instrumentation, Har/Dskt, CRC Press, 1997.

Witzel, O., Klein, A., Wagner, S., Meffert, C., Schulz, C., and Ebert, V.: High-speed tunable diode laser absorption spectroscopy for sampling-free in-cylinder water vapor concentration measurements in an optical IC engine, Appl. Phys. B, 109, 521-532, doi:10.1007/s00340-012-5225-0, 2012.

Wolfrum, J., Dreier, T., Ebert, V., and Schulz, C.: Laser-Based Combustion Diagnostics, in Encyclopedia of Analytical Chemistry, edited by: Meyers, R. A., John Wiley: Chichester, 2nd Edn., 33 pp., 2011.

Wunderle, K., Fernholz, T., and Ebert, V.: Selection of optimal absorption lines for tunable laser absorption spectrometers, in VDI Berichte (1959) VDI Verlag, Düsseldorf, 137-148, 2006.

Wunderle, K., Al-Zaitone, B., Pašti, I., Wagner, S., Hunsmann, S., Tropea, C., and Ebert, V.: TDLAS-Spektrometer zur räumlich aufgelösten absoluten Wasserdampfbestimmung um akustisch levitierte Einzeltröpfchen, in VDI Berichte (2047) VDI Verlag, Düsseldorf, 103-112, 2008.

Xie, B., Zhang, Q., and Ying, Y.: Trends in Precipitable Water and Relative Humidity in China: 1979-2005, J. Appl. Meteorol. Climatol., 50, 1985-1994, doi:10.1175/2011JAMC2446.1, 2011.

Zöger, M., Engel, A., McKenna, D. S., Schiller, C., Schmidt, U., and Woyke, T.: Balloon-borne in situ measurements of stratospheric $\mathrm{H}_{2} \mathrm{O}, \mathrm{CH}_{4}$ and $\mathrm{H} 2$ at midlatitudes, J. Geophys. Res., 104, $1817-$ 1825, doi:10.1029/1998JD100024, 1999a.

Zöger, M., Afchine, A., Eicke, N., Gerhards, M.-T., Klein, E., McKenna, D. S., Mörschel, U., Schmidt, U., Tan, V., Tuitjer, F., Woyke, T., and Schiller, C.: Fast in situ stratospheric hygrometers: A new family of balloon-borne and airborne Lyman photofragment fluorescence hygrometers, J. Geophys. Res., 104, 1807-1816, doi:10.1029/1998JD100025, 1999b.

Zondlo, M., Paige, M. E., Massick, S. M., and Silver, J.: Vertical cavity laser hygrometer for the National Science Foundation Gulfstream-V aircraft, J. Geophys. Res., 115, 20309, doi:10.1029/2010JD014445, 2010. 